\title{
Effects of the Educational Use of Music on 3- to 12-Year-Old Children's Emotional Development: A Systematic Review
}

\author{
José Salvador Blasco-Magraner ${ }^{1}\left(\mathbb{D}\right.$, Gloria Bernabe-Valero ${ }^{2, *} \mathbb{( D}$, Pablo Marín-Liébana ${ }^{1}(\mathbb{C}$ \\ and Carmen Moret-Tatay $2 \mathbb{D}$ \\ 1 Department of Teaching of Musical, Visual and Corporal Expression, Faculty of Teacher Training, \\ Universitat de València, 46010 Valencia, Spain; j.salvador.blasco@uv.es (J.S.B.-M.); \\ pablo.marin-liebana@uv.es (P.M.-L.) \\ 2 Faculty of Psychology, Universidad Católica de Valencia "San Vicente Mártir", 46001 Valencia, Spain; \\ mariacarmen.moret@ucv.es \\ * Correspondence: gloria.bernabe@ucv.es
}

\section{check for}

updates

Citation: Blasco-Magraner, J.S.; Bernabe-Valero, G.; Marín-Liébana, P.; Moret-Tatay, C. Effects of the Educational Use of Music on 3- to 12-Year-Old Children's Emotional Development: A Systematic Review. Int. J. Environ. Res. Public Health 2021, 18, 3668. https://doi.org/10.3390/ ijerph18073668

Academic Editors: Simona De Stasio and Carmen Berenguer

Received: 4 March 2021

Accepted: 29 March 2021

Published: 1 April 2021

Publisher's Note: MDPI stays neutral with regard to jurisdictional claims in published maps and institutional affiliations.

Copyright: (c) 2021 by the authors. Licensee MDPI, Basel, Switzerland This article is an open access article distributed under the terms and conditions of the Creative Commons Attribution (CC BY) license (https:// creativecommons.org/licenses/by/ $4.0 /)$.

\begin{abstract}
Interest in the study of emotions in education has grown in recent years. Some of our modern challenges, such as constantly adapting to new scenarios or the need for team work have justified the introduction of emotional competence into educational systems, while diverse studies confirm the relationship between music and emotional intelligence, so that the former could be used as a tool to develop the latter. The aim of this work was to examine the evidence for positive effects of music on the emotions of 3- to 12-year-old children, to which end a systematic review was carried out. Two reviewers independently evaluated 424 studies that were identified in MEDLINE, Psycinfo, and CINAHL databases, in order to determine whether they met the stated inclusion criteria. A total of 26 articles were selected for review. The results suggest several beneficial effects of music on children's development, such as greater emotional intelligence, academic performance, and prosocial skills. It can therefore be concluded that music should be used in school settings, not only as an important subject in itself, but also as an educational tool within other subjects.
\end{abstract}

Keywords: emotional education; music education; school environment; systematic review

\section{Introduction}

The study of emotions is a subject that has raised researchers' interest, being extended to fields ranging from philosophy, education, or psychology to health sciences. Regarding the field of education, a century ago John Dewey pointed out the importance of the social and emotional nature of the classroom and the relationship between social processes and learning [1]. However, the increase in the study of emotions in the area of education during the last two decades has given rise to a more humanistic, holistic, and socioemotional approach to educational activity [2]. Salovey \& Mayer [3] were the first to define emotional intelligence as "the ability to monitor one's own or others' feelings and emotions, to discriminate among them and to use this information and to guide one's thinking and actions". Since then, a large number of programs have emerged aiming to help educators prevent problem behaviours and to promote children's health and character development [4]. In 1994, the Collaborative to Advance Social and Emotional Learning (CASEL) was created, an organisation whose aim was to promote and implement social and emotional learning as an integral part of teaching in schools. [5].

UNESCO's well-known Report of the International Commission on Education for the 21st Century, entitled Learning: The Treasure Within [6], established four pillars on which the new education of the 21st century was based: learning to know, learning to do, learning to live together, and learning to be. The last two are closely related to emotional intelligence. Since then, research on the importance of emotional education in the field of education has not stopped growing in different scientific disciplines, especially in 
Psychology, Neurosciences and Behavioral Sciences [7]. Thus, for example, in the field of psychology there is a wide variety of works that address the study of emotions in the educational context from different topics, such as the importance of emotional competence in the classroom [8,9]; emotions and emotional regulation in the classroom [10,11]; or the importance of goals in the emotional experience of academic failure [12]. The field of neuroscience has produced numerous studies on the development of emotional regulation and the possible implications for education [13]; as well as the implications of affective and social neuroscience for educational theory [14-16]. Lastly, in the Behavioral Sciences, one can find studies as diverse as the essential characteristics of educational programs for students with emotional and behavioral disorders [17] or the professional preparation for teachers to effectively implement evidence-based practices for students with Emotional Disabilities [18].

The reasons for the significant increase in research on the relevance of emotional education in the specific educational contexts have been, in part, the fast and relentless global technological and economic and social changes which have created previously unimaginable pressures and challenges on the younger population, especially on children [19]. Moreover, the new challenges posed by today's society demand future professionals who are able to learn constantly by working in a team [20], which is a challenge in interpersonal emotional management. It is therefore necessary to have eminently social individuals with a high capacity to adapt to the constant changes that today's society demands [21]. For this reason, the educational systems of the most developed countries include in their educational programs the development of individual's emotional competencies [22]. Social and emotional education is defined as "the educational process by which an individual develops intrapersonal and interpersonal competence and resilience skills in social, emotional and academic domains through curricular, embedded, relational and contextual approaches" [1] and all children should develop it in order to achieve full and integral personal formation.

What role does music education play in emotional development? In recent years, music education has gained special relevance as part of the curricula of compulsory education in most Western countries [23], both for its learning benefits in itself [24-26], as well as for its ability to promote the learning of other disciplines [27,28]. Music has a remarkable capacity to express, transmit, and evoke various emotions and affections in human beings [29,30], regardless of their nationality or culture [31].

In the last two decades the research on music and its ability to generate emotions in humans has been systematized [32-38]. Numerous studies affirm the ability of music to trigger physiological responses, such as changes in the heart rate, skin temperature, and conductance, respiration and hormone secretion [39-43]. Other studies claim that music aids emotional regulation [44-47] and some have shown that music stimulates the cognitive aspect [48-51]. Ultimately, music is described as multidimensional and researchers have categorised it by its arousal properties, emotional quality, and structural characteristics [52].

The link between music and emotion has contributed to the value of music as a discipline that can be implemented in formal education to develop students' emotional competence $[2,53]$. One of the advantages of musical activities is that they mostly require collective participation, which requires cooperation and coordination on the part of the members of a society [54], making them useful tools for the advancement of socioemotional development. In addition, the social interactions required for music-making offer many opportunities for students to develop their abilities to evaluate their own feelings and at the same time try to relate constructively to the feelings of others [55]. According to Pellitteri [56] there are five ways in which music education and social-emotional learning are complementary: music can be used as an emotional stimulus; it can be an aesthetic experience; it can be used for relaxation and imagery; music-making is a form of selfexpression; and music-making can be a form of group experience [57].

Music education thus has a strong impact on children and young people's intellectual, social, and personal development and therefore on pupils' psychological well-being [58,59]. 
To our knowledge, no systematic review has been carried out on how the educational use of music affects the emotional development of children between 3 and 12 years of age. In order to answer this question, a systematic review was carried out to obtain as many studies as possible that explore this developmental stage. The information obtained from all of the studies on this specific subject was thus synthesized and partial or biased conclusions were avoided by referring to the available documents or the authors' subjective inclusion criteria.

\section{Materials and Methods}

To find out the effects of the educational use of music on 1-3-year-old children's emotional development, a systematic review was carried out following the Preferred Reporting Items for Systematic Reviews and Meta-Analyses (PRISMA) statement guidelines. The question under study was: How does the use of music in the educational field affect the emotional development of children aged between 3 and 12 years old?

The articles were selected in different stages by two independent reviewers, who independently extracted data from articles that had been deemed eligible in the selection stage. Discrepancies at further stages were resolved by consensus with a third researcher, so that the process can be described in two main stages. First, the researchers read the titles and abstracts individually, and secondly, the full text to finally compare agreement. The inclusion and exclusion criteria were the same in both stages. In the case of a disagreement, a third reviewer was consulted. The articles rejected in the first or second stage for not meeting the inclusion criteria had the reason for their exclusion described in the results section. Data extraction was based on the recommendations of the "Cochrane Handbook for Systematic Reviews", including the following information: (i) general information about the study (e.g., author's citation, and country of origin); (ii) methodology (e.g., duration/followup of the study and design and type of music intervention); (iii) information related to the sample (e.g., selection method, sample size, age and sex distribution); (iv) information related to the outcome (e.g., effects in the emotion variable); and (v) additional information (e.g., statistical methods involved or size effects).

Studies were identified in the MEDLINE, Psycinfo, and CINAHL Web of Science and EBSCO databases through EBSCO and WOS (ISI Web of Knowledge) to determine whether they met the stated inclusion criteria. General search terms with the controlled descriptors for each database were used, employing the Medical Subject Heading (MeSH) from MEDLINE terms, and the descriptors and terms published in the literature. As this is a relatively recent field of study there is not yet a general consensus on the definitions of several analysis variables and categories on the relations between music and emotional development, we opted to use generic key words, which opened up a large number of papers. The two main words were music and school, with the addition of school to reduce the search to the educational field.

To connect these terms, we used the Boolean terms "AND" and "OR" to expand and restrict the search spectrum. In addition, a manual search was also performed. The total electronic search of all databases was performed between August and December 2020. The final syntax is defined as follows: "Music" AND "Emotion" AND "School". In this way, we tried to restrict the sample to studies that focused on the relationship between music and emotions in educational contexts.

\subsection{Inclusion Criteria}

To be included in the review, articles had to meet the following requirements: (i) the sample of a study had to be children between 3 and 12 years of age, i.e., who were in pre-primary or primary school, to adjust the research question to the selected age range; (ii) it had to be an empirical study (i.e., cross-sectional, cohort, or case-control studies) to guarantee any conclusions drawn from our observations of reality; (iii) it had to measure the role of music in emotion so as to draw conclusions on the effect of music in primary education on the children's emotional development; and (iv) it must have been published 
since 2000, in order to analyze studies from the last 20 years, when this new field of knowledge was developed.

\subsection{Exclusion Criteria}

Articles that met one of the following exclusion criteria were not added to the analyzed sample: (i) those not expressly measuring emotions, dealing with the subject matter in an indirect or secondary way, i.e., those that did not directly deal with the relation between music and emotional development in spite of containing the key words; (ii) those that were non-empirical theoretical or bibliographical studies; (iii) those that were single case studies, due to the difficulty of generalizing any results obtained; (iii) those that included sample ages outside the selected range, i.e., studies on children less than 3 years old, adolescents and adults; and (iv) those that were grey literature or non-peer reviewed journal articles, to guarantee the quality of the reviewed papers.

\section{Results}

The results obtained in the systematic review are presented below. After a selective process using the PRISMA protocol flowchart as a reference [60], the results of the systematic review are depicted in Figure 1. The sample analyzed reached a total of 26 scientific articles. The number of articles excluded according to the different criteria is shown in Table 1 and a summary of the content developed from the analyzed articles can be consulted in Table 2. Below is a description of the sample used and a narrative summary of the different papers, grouped according to subject matter.

Table 1. Table showing reasons items were excluded.

\begin{tabular}{cc}
\hline Exclusion Criteria & Total Items Excluded \\
\hline The work does not specifically address the research question & 259 \\
\hline Not an empirical study & 58 \\
\hline Children were not within the age range 3-12 years old & 41 \\
\hline Sample of participants included mixed ages & 12 \\
\hline Sample $n=1$ & 3 \\
\hline Not an article & 7 \\
\hline
\end{tabular}




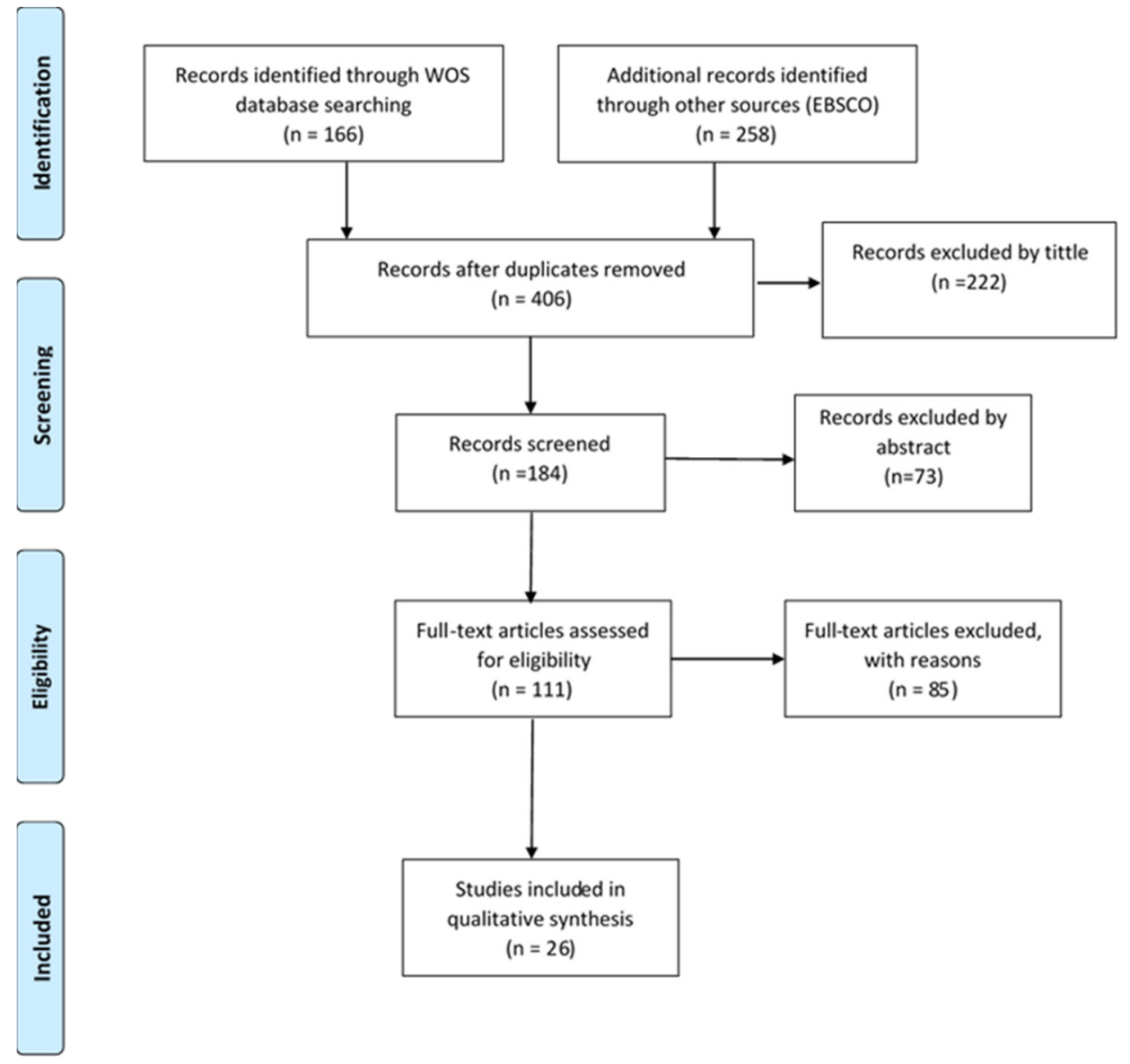

Figure 1. Preferred Reporting Items for Systematic Reviews and Meta-Analyses (PRISMA) flowchart to show study selection process [60]. 
Table 2. Summary of findings.

(A)

\begin{tabular}{|c|c|c|c|c|c|c|c|c|c|}
\hline Study & $\mathbf{N}$ & Age & $\begin{array}{l}\text { Educational } \\
\text { Setting }\end{array}$ & $\begin{array}{l}\text { Primary Purpose } \\
\text { of Study }\end{array}$ & Study Design & Music Variables & $\begin{array}{l}\text { Emotion } \\
\text { Variables }\end{array}$ & Music Style & $\begin{array}{c}\text { Relevant Data } \\
\text { Collection Measures }\end{array}$ \\
\hline $\begin{array}{c}\text { Moore \& } \\
\text { Hanson- } \\
\text { Abromeit } \\
{[61]}\end{array}$ & 8 & 3 to 5 & Preschool & $\begin{array}{l}\text { To examine feasibility } \\
\text { and preliminary } \\
\text { efficacy of the Musical } \\
\text { Contour Regulation } \\
\text { Facilitation (MCRF) } \\
\text { intervention, a } \\
\text { multi-session strategy } \\
\text { for promoting ER } \\
\text { development in } \\
\text { preschoolers }\end{array}$ & Case study & $\begin{array}{l}\text { To participate in } \\
\text { the MCRF } \\
\text { intervention }\end{array}$ & $\begin{array}{l}\text { Emotion understanding } \\
\text { accuracy; emotional } \\
\text { regulation; child's } \\
\text { expression of emotion }\end{array}$ & Not specified & $\begin{array}{c}\text { Language Development } \\
\text { Survey (part of ASEBA; } \\
\text { Achenbach \& Rescorla, 2000); } \\
\text { Emotion Regulation } \\
\text { Checklist (ERC; Shields \& } \\
\text { CIcchetti, 1997, 1998); Child } \\
\text { Behavior Checklist (CBCL) } \\
\text { and Caregiver-Teacher } \\
\text { Report Form (C-TRF), both } \\
\text { part of the ASEBA } \\
\text { (Asenbach \& Rescorla, 2000) }\end{array}$ \\
\hline $\begin{array}{c}\text { Boone \& } \\
\text { Cunningham } \\
\text { [62] }\end{array}$ & 47 & 3 to 6 & Preschool & $\begin{array}{l}\text { To determine if } \\
\text { children can } \\
\text { accurately express the } \\
\text { emotional meaning in } \\
\text { music through } \\
\text { expressive movement }\end{array}$ & Observational & $\begin{array}{l}12 \text { music segments } \\
\text { previously } \\
\text { identified as } \\
\text { belonging to one } \\
\text { emotional } \\
\text { category } \\
\text { (happiness, } \\
\text { sadness, ange } \\
\text { or fear) }\end{array}$ & $\begin{array}{l}\text { Happiness, sadness, } \\
\text { anger, or fear }\end{array}$ & $\begin{array}{l}\text { (1) Romanian Rhapsody, } \\
\text { Opus 11/Enesco; (2) Peter } \\
\text { Gynt; Ase's Death, Suite No. } \\
\text { 1, Opus 46/Grieg; (3) Theme } \\
\text { to Lifeforce/Mancini; (4) } \\
\text { Surprise Attack The Wrath of } \\
\text { Khan/Horner; (5) Concerto } \\
\text { in D, Opus 35/Tschaikovsky; } \\
\text { (6) The Humorous } \\
\text { Song/Lyadov (7) The Rite of } \\
\text { Spring/Stravinsky (8) The } \\
\text { Red Poppy, the Russian } \\
\text { Sailor's Dance/Gliere (9) } \\
\text { Winter Games/Foster (10) } \\
\text { Anvil of Crom, } \\
\text { Conan/Poledouris (11) } \\
\text { Venus/Holst; (12) The Walls } \\
\text { Converge, Star } \\
\text { Wars. Williams }\end{array}$ & $\begin{array}{l}\text { Ad hoc observational } \\
\text { registration }\end{array}$ \\
\hline $\begin{array}{c}\text { Brown \& Sax } \\
{[63]}\end{array}$ & 205 & 4 & Preschool & $\begin{array}{l}\text { To examine the impact } \\
\text { of arts-integrated } \\
\text { preschool } \\
\text { programming on the } \\
\text { emotional func-tioning } \\
\text { of low-income } \\
\text { children at risk for } \\
\text { school problems }\end{array}$ & Correlational & $\begin{array}{l}\text { Participate in an } \\
\text { arts integrated } \\
\text { preschool } \\
\text { program }\end{array}$ & $\begin{array}{l}\text { Emotion understanding, } \\
\text { empathy, emotional } \\
\text { lability, anger reactivity, } \\
\text { negative emotion } \\
\text { intensity }\end{array}$ & $\begin{array}{l}\text { Not specified: music, dance, } \\
\text { and visual arts class }\end{array}$ & $\begin{array}{c}\text { Peabody Picture Vocabulary } \\
\text { Test-III (PPVT-III; Dunn \& } \\
\text { Dunn, 1997); Emotion } \\
\text { Regulation Checklist (ERC; } \\
\text { Shields \& Cicchetti, 1997); } \\
\text { and an adapted version of } \\
\text { the Affex system, which is } \\
\text { grounded in DET (izard, } \\
\text { Dougherty, \& } \\
\text { Hembree, 1989) }\end{array}$ \\
\hline
\end{tabular}


Table 2. Cont.

\begin{tabular}{|c|c|c|c|c|c|c|c|c|c|}
\hline Study & $\mathbf{N}$ & Age & $\begin{array}{l}\text { Educational } \\
\text { Setting }\end{array}$ & $\begin{array}{c}\text { Primary Purpose } \\
\text { of Study }\end{array}$ & Study Design & Music Variables & $\begin{array}{l}\text { Emotion } \\
\text { Variables }\end{array}$ & Music Style & $\begin{array}{c}\text { Relevant Data } \\
\text { Collection Measures }\end{array}$ \\
\hline $\begin{array}{l}\text { Habibi et al. } \\
\text { [64] }\end{array}$ & 45 & 6 to 7 & Out of school & $\begin{array}{l}\text { To determine whether } \\
\text { children who } \\
\text { participate in musical } \\
\text { training were different, } \\
\text { prior to training, from } \\
\text { children in the control } \\
\text { groups in terms of } \\
\text { cognitive, motor, } \\
\text { musical, emotional, } \\
\text { and social } \\
\text { measures }\end{array}$ & $\begin{array}{l}\text { Cross-sectional } \\
\text { between subjects; } \\
\text { experimental } \\
\text { (controlled trial, } \\
\text { non-randomized } \\
\text { sample) }\end{array}$ & $\begin{array}{l}\text { To be involved in } \\
\text { a systematic and } \\
\text { high intensity } \\
\text { musicaltraining, } \\
\text { and music } \\
\text { perception }\end{array}$ & $\begin{array}{l}\text { Emotional recognition } \\
\text { and empathy }\end{array}$ & $\begin{array}{l}\text { Not specified. Gordon's } \\
\text { primary measures of music } \\
\text { audiation (PMMA) requires } \\
\text { children to listen to a } \\
\text { recording of } 40 \text { pairs of } \\
\text { simple rhythms and } 40 \text { pairs } \\
\text { of tone sequences and make } \\
\text { a same/different judgment } \\
\text { for each pair by circling a } \\
\text { pair of same or different } \\
\text { faces (Gordon, 1986). }\end{array}$ & $\begin{array}{c}\text { Auditory analysis test } \\
\text { (Rosner and Simon, 1971); } \\
\text { Gordon's primary measures } \\
\text { of music audiation (PMMA; } \\
\text { Gordon, 1986); Reading the } \\
\text { Mind in the Eyes } \\
\text { (Baron-Cohen et al., 2001); } \\
\text { Index of Empathy for } \\
\text { Children (Bryant, 1982); } \\
\text { video emotion test } \\
\text { (Goldstein adn Winner, } \\
\text { 2012); Helping and sharing } \\
\text { test (ad hoc) }\end{array}$ \\
\hline $\begin{array}{l}\text { Nieminen } \\
\text { et al. [65] }\end{array}$ & 127 & 6 to 9 & $\begin{array}{l}\text { Elementary } \\
\text { school }\end{array}$ & $\begin{array}{l}\text { To investigate the } \\
\text { effects of age, gender, } \\
\text { and music education } \\
\text { on musical preference, } \\
\text { musical emotion } \\
\text { recognition, and the } \\
\text { use of the aesthetic } \\
\text { categories for music }\end{array}$ & $\begin{array}{l}\text { Cross-sectional } \\
\text { between subjects; } \\
\text { experimental } \\
\text { (non-randomized } \\
\text { sample) }\end{array}$ & $\begin{array}{l}\text { Musical } \\
\text { preference and } \\
\text { musical mode } \\
\text { (major, minor and } \\
\text { free tonal) }\end{array}$ & $\begin{array}{l}\text { Beauty, ugliness, } \\
\text { happiness and sadness }\end{array}$ & $\begin{array}{l}\text { Three short musical pieces } \\
\text { (20 s each) resembling } \\
\text { familiar children's songs of } \\
\text { Western music }\end{array}$ & $\begin{array}{c}\text { Ad hoc questionnaire } \\
\text { and task }\end{array}$ \\
\hline $\begin{array}{c}\text { Ramdane et al. } \\
{[66]}\end{array}$ & 186 & 6 to 12 & $\begin{array}{l}\text { Elementary } \\
\text { school }\end{array}$ & $\begin{array}{l}\text { To investigate the } \\
\text { usefulness of using } \\
\text { music and songs by } \\
\text { Islamic Education } \\
\text { teachers }\end{array}$ & Correlational & $\begin{array}{l}\text { Using music at } \\
\text { the classroom }\end{array}$ & Emotional awareness & Not specified & $\begin{array}{l}\text { Ad hoc questionnaire } \\
\text { and interviews }\end{array}$ \\
\hline $\begin{array}{c}\text { Jeremic et al. } \\
\text { [67] }\end{array}$ & 89 & 7 & $\begin{array}{l}\text { Elementary } \\
\text { school }\end{array}$ & $\begin{array}{l}\text { To study the effect of } \\
\text { vocal performance as a } \\
\text { teaching method in } \\
\text { relation to the } \\
\text { social-emotional } \\
\text { competencies (SEC) } \\
\text { of pupils }\end{array}$ & $\begin{array}{l}\text { Cross-sectional } \\
\text { between subjects; } \\
\text { experimental } \\
\text { (controlled trial, } \\
\text { non-randomized } \\
\text { sample) }\end{array}$ & $\begin{array}{l}\text { The vocal } \\
\text { performance } \\
\text { teaching method }\end{array}$ & $\begin{array}{l}\text { Empathy, impulsivity, } \\
\text { emotional control } \\
\text { and reactions }\end{array}$ & $\begin{array}{l}\text { Songs by ear where the basic } \\
\text { psychological processes take } \\
\text { place when singing } \\
\text { accompanied by elements of } \\
\text { vocal technique. Perceptual } \\
\text { characteristics include } \\
\text { singing by ear, tone of voice } \\
\text { and resonance }\end{array}$ & $\begin{array}{l}\text { Scale for assessment of } \\
\text { social-emotional } \\
\text { competencies of } \\
\text { students (SEC) }\end{array}$ \\
\hline $\begin{array}{c}\text { Schellenberg } \\
\& \text { Mankarious } \\
\text { [68] }\end{array}$ & 60 & 7 to 8 & Out of school & $\begin{array}{l}\text { To examine whether } \\
\text { music training in } \\
\text { childhood is predictive } \\
\text { of understanding } \\
\text { emotions }\end{array}$ & Correlational & $\begin{array}{l}\text { Child's history of } \\
\text { music lessons }\end{array}$ & Emotion recognition & Not specified & $\begin{array}{c}\text { Test of Emotion } \\
\text { Comprehension (TEC; Pons } \\
\text { \& Harris, 2000), and } \\
\text { Weschler Abbreviated Scale } \\
\text { of Intelligence (WASI; } \\
\text { Weschler, 1999) }\end{array}$ \\
\hline
\end{tabular}


Table 2. Cont.

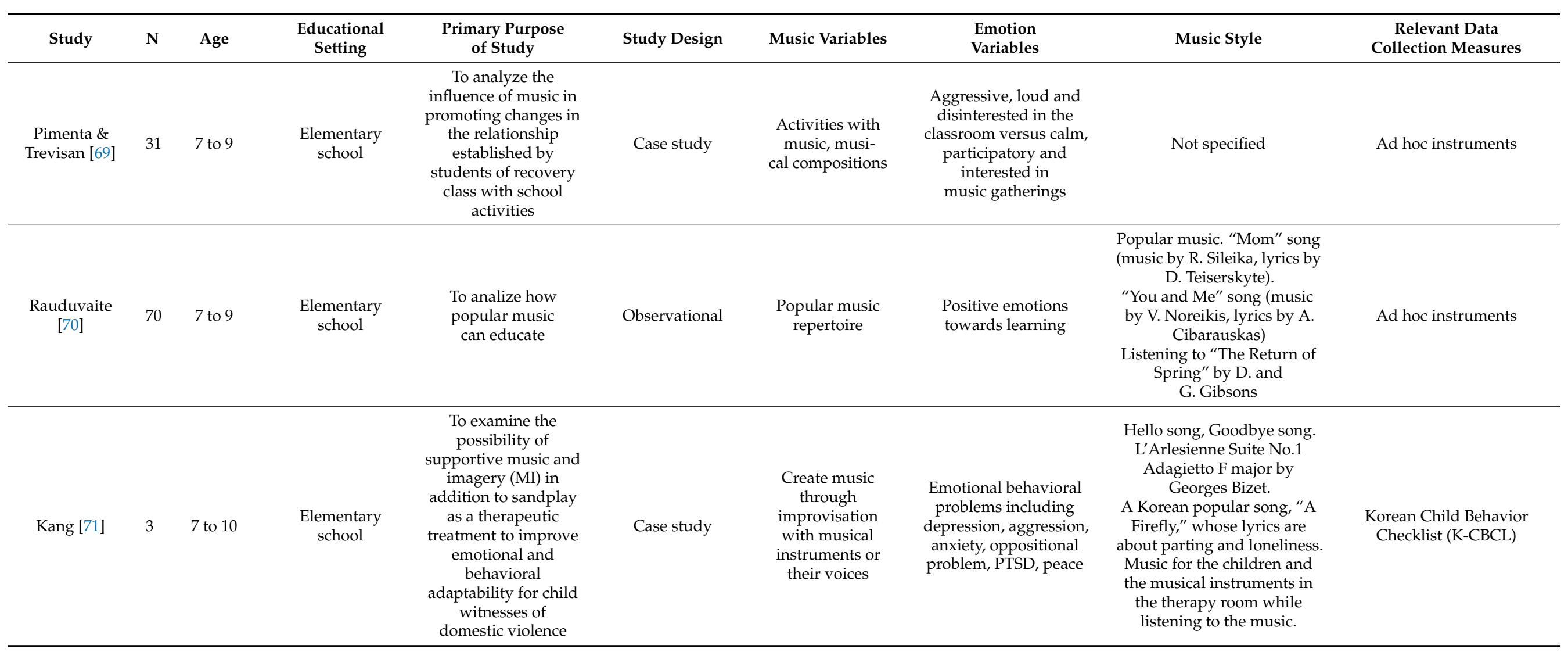


Table 2. Cont.

\begin{tabular}{|c|c|c|c|c|c|c|c|c|c|}
\hline Study & $\mathbf{N}$ & Age & $\begin{array}{l}\text { Educational } \\
\text { Setting }\end{array}$ & $\begin{array}{c}\text { Primary Purpose } \\
\text { of Study }\end{array}$ & Study Design & Music Variables & $\begin{array}{l}\text { Emotion } \\
\text { Variables }\end{array}$ & Music Style & $\begin{array}{c}\text { Relevant Data } \\
\text { Collection Measures }\end{array}$ \\
\hline Soulier [72] & 234 & 7 to 11 & $\begin{array}{l}\text { Elementary } \\
\text { school }\end{array}$ & $\begin{array}{l}\text { To study the effect of } \\
\text { an emotional } \\
\text { induction by music on } \\
\text { the grammatical } \\
\text { spelling performances } \\
\text { of primary- } \\
\text { school pupils }\end{array}$ & $\begin{array}{l}\text { Cross-sectional } \\
\text { between subjects: } \\
\text { experimental } \\
\text { (non-randomized) }\end{array}$ & $\begin{array}{l}\text { Exposure to } \\
\text { musical excerpts } \\
\text { judged to be } \\
\text { emotionally } \\
\text { neutral, happy, } \\
\text { and sad }\end{array}$ & $\begin{array}{l}\text { Positive, negative } \\
\text { emotions and } \\
\text { neutral emotions }\end{array}$ & $\begin{array}{c}\text { Musical excerpts with } \\
\text { emotional valences: positive, } \\
\text { negative and neutral: (1) } \\
\text { Adagio en sol } \\
\text { mineur-Tomaso Albinoni; } \\
\text { (2) Nocturne C\# Min op. } \\
\text { Postuma-Frédéric Chopin (3) } \\
\text { Prélude no 4-Frédéric } \\
\text { Chopin; (4) La mort d'Ase. } \\
\text { Peer Gynt-Edvard Grieg; (5) } \\
\text { Adagio pour cordes-Samuel } \\
\text { Barber; (6) Danse des } \\
\text { heures-Amilcare Ponchielli; } \\
\text { (7) Le Sacre du } \\
\text { printemps-Igor Stravinsky; } \\
\text { (8) Dans l'Antre du roi de la } \\
\text { montage-Edvard Grieg; (9) } \\
\text { Marche Slave-Piotr Ilitch } \\
\text { Tchaïkovsky; (10) Danse } \\
\text { Arabe-Piotr Ilitch } \\
\text { Tchaïkovsky; (11) Danse } \\
\text { chinoise-Piotr Ilitch } \\
\text { Tchaïkovsky; (12) Le } \\
\text { Carnaval des } \\
\text { animaux-Camille } \\
\text { Saint-Saëns; (13) Au } \\
\text { matin-Edvard Grieg; (14) } \\
\text { Bolero-Maurice Ravel; (15) } \\
\text { Symphonie n 6-Ludwig } \\
\text { van Beethoven }\end{array}$ & $\begin{array}{c}\text { The ECS Cycle III spelling } \\
\text { test (Evaluation of School } \\
\text { Skills, Cycle of Advanced } \\
\text { Studies developed by } \\
\text { Khomsi, 1998) }\end{array}$ \\
\hline $\begin{array}{c}\text { Kim \& Kim } \\
{[73]}\end{array}$ & 60 & 7 to 12 & $\begin{array}{l}\text { Elementary } \\
\text { school }\end{array}$ & $\begin{array}{l}\text { To determine the } \\
\text { effects of a musical } \\
\text { instrument } \\
\text { performance program } \\
\text { on emotional } \\
\text { intelligence, anxiety, } \\
\text { and aggression }\end{array}$ & $\begin{array}{l}\text { Cross-sectional } \\
\text { between subjects; } \\
\text { experimental } \\
\text { (nonequivalent } \\
\text { control group } \\
\text { pretest-posttest } \\
\text { study) }\end{array}$ & $\begin{array}{l}\text { Musical } \\
\text { instrument } \\
\text { performance } \\
\text { program }\end{array}$ & $\begin{array}{l}\text { Emotional intelligence, } \\
\text { anxiety, and aggression }\end{array}$ & $\begin{array}{l}\text { Not specified. A children's } \\
\text { song, sonata, or the flute part } \\
\text { of an ensemble work for } \\
\text { their level. }\end{array}$ & $\begin{array}{l}\text { The Emotional Intelligence } \\
\text { Scale, the Trait Anxiety } \\
\text { Inventory, and the } \\
\text { Aggression Scale }\end{array}$ \\
\hline
\end{tabular}


Table 2. Cont.

\begin{tabular}{|c|c|c|c|c|c|c|c|c|c|}
\hline Study & $\mathbf{N}$ & Age & $\begin{array}{l}\text { Educational } \\
\text { Setting }\end{array}$ & $\begin{array}{l}\text { Primary Purpose } \\
\text { of Study }\end{array}$ & Study Design & Music Variables & $\begin{array}{l}\text { Emotion } \\
\text { Variables }\end{array}$ & Music Style & $\begin{array}{c}\text { Relevant Data } \\
\text { Collection Measures }\end{array}$ \\
\hline $\begin{array}{l}\text { Schellenberg } \\
\text { et al. [74] }\end{array}$ & 84 & 8 & $\begin{array}{l}\text { Elementary } \\
\text { school }\end{array}$ & $\begin{array}{l}\text { To examine whether } \\
\text { social benefits are } \\
\text { accrued from more } \\
\text { typical group music } \\
\text { training, specifically } \\
\text { an existing program } \\
\text { that was designed } \\
\text { with music pedagogy } \\
\text { as its focus }\end{array}$ & $\begin{array}{l}\text { Cross-sectional } \\
\text { between subjects; } \\
\text { experimental } \\
\text { (controlled trial, } \\
\text { non-randomized } \\
\text { sample) }\end{array}$ & $\begin{array}{l}\text { Attending public } \\
\text { schools that } \\
\text { incorporated this } \\
\text { specialized } \\
\text { program }\end{array}$ & $\begin{array}{l}\text { Emotion comprehension, } \\
\text { sympathy and } \\
\text { prosocial skills }\end{array}$ & $\begin{array}{l}\text { The repertoire includes } \\
\text { arrangements of music taken } \\
\text { from classical, jazz, } \\
\text { traditional/folk, world, and } \\
\text { popular genres }\end{array}$ & $\begin{array}{l}\text { Peabody Picture Vocabulary } \\
\text { Test, Test of Emotion } \\
\text { Comprehension, and } \\
\text { Child-Report } \\
\text { Sympathy Scale }\end{array}$ \\
\hline $\begin{array}{l}\text { Teske et al. } \\
\text { [75] }\end{array}$ & 14 & 8 to 9 & $\begin{array}{l}\text { Elementary } \\
\text { school }\end{array}$ & $\begin{array}{l}\text { To determine the } \\
\text { effects of positive } \\
\text { mood induction } \\
\text { through upbeat music } \\
\text { and simulated } \\
\text { laughter on creativity }\end{array}$ & $\begin{array}{c}\text { Cross-sectional } \\
\text { between subjects; } \\
\text { experimental } \\
\text { (controlled trial, } \\
\text { non-randomized } \\
\text { sample) }\end{array}$ & $\begin{array}{l}\text { Listening to a } \\
\text { couple of minutes } \\
\text { of upbeat } \\
\text { instrumental } \\
\text { music }\end{array}$ & $\begin{array}{l}\text { Positive mood } \\
\text { and humor }\end{array}$ & $\begin{array}{l}\text { Instrumental music with a } \\
\text { lively beat }\end{array}$ & Ad hoc task \\
\hline $\begin{array}{c}\text { Venegas et al. } \\
\text { [76] }\end{array}$ & 67 & 8 to 13 & $\begin{array}{l}\text { Elementary } \\
\text { school }\end{array}$ & $\begin{array}{c}\text { To assess the } \\
\text { emotional satisfaction } \\
\text { of students while } \\
\text { using a } \\
\text { cross-disciplinary } \\
\text { software that links } \\
\text { music and maths }\end{array}$ & Case study & $\begin{array}{l}\text { Use of } \\
\text { AudioGraphics } \\
\text { software }\end{array}$ & $\begin{array}{l}7 \text { positive and } 7 \text { negative } \\
\text { (unpaired) emotions }\end{array}$ & Not specified & Ad hoc instruments \\
\hline $\begin{array}{c}\text { Tricard et al. } \\
\text { [77] }\end{array}$ & 83 & 9 to 10 & $\begin{array}{l}\text { Elementary } \\
\text { school }\end{array}$ & $\begin{array}{l}\text { To examine the } \\
\text { influence of inducing } \\
\text { positive and negative } \\
\text { emotional states on } \\
\text { deductive reasoning } \\
\text { performances }\end{array}$ & $\begin{array}{c}\text { Cross-sectional } \\
\text { between subjects; } \\
\text { experimental } \\
\text { (controlled trials, } \\
\text { non-randomized } \\
\text { sample) }\end{array}$ & $\begin{array}{l}\text { To be exposed to } \\
\text { video clips } \\
\text { and music }\end{array}$ & Happines and sadness & $\begin{array}{l}\text { Music of movies: (1) « Beach } \\
\text { Day » of Blanket Barricade; } \\
\text { (2) « Adagio for Strings » of } \\
\text { Samuel Barber; (3) } \\
\text { Background sounds } \\
\text { of nature }\end{array}$ & $\begin{array}{l}\text { Facial Action Coding System } \\
\text { (Westermann et al., 1996) }\end{array}$ \\
\hline $\begin{array}{c}\text { Yun \& Kim } \\
\text { [78] }\end{array}$ & 43 & 9 to 12 & $\begin{array}{l}\text { Elementary } \\
\text { school }\end{array}$ & $\begin{array}{l}\text { To verify whether the } \\
\text { Orff Approach is a } \\
\text { proper program to be } \\
\text { used with potentially } \\
\text { problematic children } \\
\text { in order to increase } \\
\text { their self-expression, } \\
\text { self-efficacy, and social } \\
\text { skills }\end{array}$ & $\begin{array}{l}\text { Cross-sectional } \\
\text { between subjects; } \\
\text { experimental } \\
\text { (controlled trial, } \\
\text { non-randomized } \\
\text { sample) }\end{array}$ & $\begin{array}{c}\text { The Orff } \\
\text { Approach method }\end{array}$ & $\begin{array}{l}\text { Self-expression, } \\
\text { self-efficacy, } \\
\text { self-confidence, } \\
\text { self-regulation efficacy } \\
\text { and social skills, }\end{array}$ & Not specified & $\begin{array}{l}\text { Self-expression measure } \\
\text { (Byun and Kim, 1980); } \\
\text { self-efficacy measure (Han, } \\
\text { 2002); social skills measure } \\
\text { (Mun, 2006) }\end{array}$ \\
\hline
\end{tabular}


Table 2. Cont.

\begin{tabular}{|c|c|c|c|c|c|c|c|c|c|}
\hline Study & $\mathbf{N}$ & Age & $\begin{array}{l}\text { Educational } \\
\text { Setting }\end{array}$ & $\begin{array}{c}\text { Primary Purpose } \\
\text { of Study }\end{array}$ & Study Design & Music Variables & $\begin{array}{l}\text { Emotion } \\
\text { Variables }\end{array}$ & Music Style & $\begin{array}{c}\text { Relevant Data } \\
\text { Collection Measures }\end{array}$ \\
\hline Katagiri [79] & 12 & 9 to 15 & Out of school & $\begin{array}{l}\text { To examine the effect } \\
\text { of background music } \\
\text { and song texts to teach } \\
\text { emotional } \\
\text { understanding to } \\
\text { children with autism }\end{array}$ & $\begin{array}{l}\text { Cross-sectional } \\
\text { between groups; } \\
\text { experimental } \\
\text { (controlled trial, } \\
\text { non-randomized } \\
\text { sample, } \\
\text { counterbalanced } \\
\text { treatment) }\end{array}$ & $\begin{array}{l}\text { Background music } \\
\text { or singing song, } \\
\text { both related to } \\
\text { each studied } \\
\text { emotion }\end{array}$ & $\begin{array}{l}\text { (1) Type of emotion } \\
\text { (happiness, sadness, } \\
\text { anger, and fear), and (2) } \\
\text { receptive or expressive } \\
\text { skill of emotional } \\
\text { understanding }\end{array}$ & $\begin{array}{l}\text { Not specified (background } \\
\text { music was improvised on } \\
\text { the piano and recorded by } \\
\text { four pianists skilled at } \\
\text { improvisation. Musical cues } \\
\text { were taken from Juslin } \\
\text { (2000), in which each } \\
\text { emotion was associated with } \\
\text { a specified tempo, sound } \\
\text { level, frequency spectrum, } \\
\text { articulation (legato-staccato) } \\
\text { and articulation variability. } \\
\text { Music recordings } \\
\text { representing the } \\
\text { four emotions) }\end{array}$ & $\begin{array}{l}\text { Emotional decoding and } \\
\text { encoding tasks }\end{array}$ \\
\hline $\begin{array}{c}\text { Campayo et al. } \\
\text { [80] }\end{array}$ & 3 & 10 & Out of school & $\begin{array}{l}\text { To examine the } \\
\text { relationship between } \\
\text { intrapersonal skills } \\
\text { and the musical } \\
\text { performance of } \\
\text { elementary students } \\
\text { studying the piano in a } \\
\text { Spanish conservatory }\end{array}$ & Action-research & $\begin{array}{l}\text { curricula for the } \\
\text { trird year of } \\
\text { piano studies }\end{array}$ & $\begin{array}{l}\text { Emotional awareness, } \\
\text { regulation and } \\
\text { autonomy }\end{array}$ & Not specified & $\begin{array}{l}\text { Ad hoc semi-structured } \\
\text { interviews, Teacher's diary, } \\
\text { Video-recordings, CE-360 } \\
\text { Assessment protocol }\end{array}$ \\
\hline $\begin{array}{l}\text { Cook et al. } \\
{[81]}\end{array}$ & 65 & 10 to 11 & $\begin{array}{l}\text { Elementary } \\
\text { school }\end{array}$ & $\begin{array}{l}\text { This study evaluated } \\
\text { the impact of } \\
\text { music-based contact } \\
\text { with autistic peers on } \\
\text { the attitudes, emotions } \\
\text { and behaviors of } \\
\text { neurotypical children }\end{array}$ & $\begin{array}{l}\text { Cross-sectional } \\
\text { between subjects; } \\
\text { experimental } \\
\text { (controlled trial, } \\
\text { non-randomized } \\
\text { sample) }\end{array}$ & $\begin{array}{l}\text { Music-based } \\
\text { contact with } \\
\text { autistic peers }\end{array}$ & $\begin{array}{c}\text { Prosocial } \\
\text { and sympathy }\end{array}$ & $\begin{array}{l}\text { Not specified (They received } \\
11 \text { weekly singing classes - } \\
35 \text { min in length-that were } \\
\text { specifically designed to help } \\
\text { children develop their social } \\
\text { skills, musical engagement } \\
\text { and communication } \\
\text { between singers) }\end{array}$ & $\begin{array}{l}\text { Social Behaviour } \\
\text { Questionnaire (Tremblay } \\
\text { et al., 1991) modified; } \\
\text { Child-Report Sympathy } \\
\text { Scale (Eisenberg et al., 1996) } \\
\text { modified; victim scale from } \\
\text { the Bullying Prevalence } \\
\text { Questionnaire (Rigby and } \\
\text { Slee, 1993); bully scale from } \\
\text { the Bullying Prevalence } \\
\text { Questionnaire (Rigby and } \\
\text { Slee, 1993); and ad } \\
\text { hoc questionnaire }\end{array}$ \\
\hline
\end{tabular}


Table 2. Cont.

\begin{tabular}{|c|c|c|c|c|c|c|c|c|c|}
\hline Study & $\mathbf{N}$ & Age & $\begin{array}{l}\text { Educational } \\
\text { Setting }\end{array}$ & $\begin{array}{l}\text { Primary Purpose } \\
\text { of Study }\end{array}$ & Study Design & Music Variables & $\begin{array}{l}\text { Emotion } \\
\text { Variables }\end{array}$ & Music Style & $\begin{array}{c}\text { Relevant Data } \\
\text { Collection Measures }\end{array}$ \\
\hline Lebaka [82] & 8 & 10 to 11 & $\begin{array}{l}\text { Elementary } \\
\text { school }\end{array}$ & $\begin{array}{l}\text { To examine whether } \\
\text { selected songs songs } \\
\text { are relevant for } \\
\text { enriching attitudes } \\
\text { and cultural values } \\
\text { of children }\end{array}$ & Descriptive & $\begin{array}{l}31 \text { songs collected } \\
\text { from Bapedi } \\
\text { women. } \\
\text { Techniques of } \\
\text { playing brass and } \\
\text { percussion } \\
\text { instruments; } \\
\text { singing and } \\
\text { reading music; } \\
\text { and improvisation }\end{array}$ & $\begin{array}{l}\text { Self-confidence and } \\
\text { prosocial }\end{array}$ & $\begin{array}{l}\text { Traditional Pedi } \\
\text { religious songs }\end{array}$ & Ad hoc instruments \\
\hline Ho et al. [83] & 101 & 10 to 12 & $\begin{array}{l}\text { Elementary } \\
\text { school }\end{array}$ & $\begin{array}{l}\text { To assess the effects of } \\
12 \text { weeks of school } \\
\text { counselorled } \\
\text { drumming on } \\
\text { social-emotional } \\
\text { in two fifth-grade } \\
\text { intervention } \\
\text { classrooms }\end{array}$ & $\begin{array}{l}\text { Cross-sectional } \\
\text { between subjects; } \\
\text { experimental } \\
\text { (controlled trial, } \\
\text { non-randomized } \\
\text { sample) }\end{array}$ & $\begin{array}{l}\text { Participation in a } \\
12 \text { weeks of school- } \\
\text { counselorled } \\
\text { drumming } \\
\text { program }\end{array}$ & $\begin{array}{l}\text { Emotion management } \\
\text { (anxiety, depression, } \\
\text { withdrawn, somatic } \\
\text { complaints, } \\
\text { rule-breaking, } \\
\text { etc.) }\end{array}$ & $\begin{array}{l}\text { Not specified (A hybrid of } \\
\text { activities used in } \\
\text { contemporary drum circles) }\end{array}$ & $\begin{array}{l}\text { Teacher's Report Form } \\
\text { (teacher version of the Child } \\
\text { Behaviour Checklist) }\end{array}$ \\
\hline Porta [84] & 163 & 10 to 12 & $\begin{array}{l}\text { Elementary } \\
\text { school }\end{array}$ & $\begin{array}{l}\text { To discover the } \\
\text { favorite audiovisuals } \\
\text { of a sample of } 11-12 \\
\text { year old children. To } \\
\text { learn what meaning } \\
\text { and sense music has } \\
\text { for them. }\end{array}$ & Correlational & $\begin{array}{l}\text { Audiovisuals with } \\
\text { or without music }\end{array}$ & Emotional bond & $\begin{array}{l}\text { Selection of } 14 \text { sequences } \\
\text { from the children's favorite } \\
\text { audiovisuals: film; cartoons } \\
\text { series; documentary }\end{array}$ & Ad hoc questionnaires \\
\hline $\begin{array}{l}\text { Kawakami \& } \\
\text { Katahira [85] }\end{array}$ & 84 & 11.9 & $\begin{array}{l}\text { Elementary } \\
\text { school }\end{array}$ & $\begin{array}{l}\text { To investigate the } \\
\text { emotional mechanisms } \\
\text { that make people } \\
\text { experience pleasant } \\
\text { emotion when } \\
\text { listening to sad music } \\
\end{array}$ & Observational & $\begin{array}{l}\text { Listening to two } \\
\text { minor pieces } \\
\text { considered sad by } \\
\text { previous studies; } \\
\text { Musical } \\
\text { preference }\end{array}$ & $\begin{array}{l}\text { Emotional state (among } \\
50 \text { emotions) }\end{array}$ & $\begin{array}{c}\text { Granados's Allegro } \\
\text { de Concierto (G minor), and } \\
\text { Glinka's La Separation } \\
\text { (F minor), }\end{array}$ & $\begin{array}{c}50 \text { emotion-related } \\
\text { descriptive words and } \\
\text { phrases on a } 1 \text { to } 5 \text { scale (ad } \\
\text { hoc); Interpersonal } \\
\text { Reactivity Index for children } \\
\text { (Hasegawa et al., 2009) }\end{array}$ \\
\hline Su et al. [86] & 62 & 11 to 12 & $\begin{array}{l}\text { Elementary } \\
\text { school }\end{array}$ & $\begin{array}{l}\text { To examine the effects } \\
\text { of the Mozart piece } \\
\text { K.448 on the learning } \\
\text { anxiety, cognitive load, } \\
\text { reading rates and } \\
\text { reading } \\
\text { comprehension of } \\
\text { students for reading } \\
\text { e-books }\end{array}$ & $\begin{array}{c}\text { Cross-sectional } \\
\text { within subjects; } \\
\text { experimental } \\
\text { (non-randomized } \\
\text { sample) }\end{array}$ & $\begin{array}{l}\text { Being exposed to } \\
\text { background music } \\
\text { (K.448) }\end{array}$ & Anxiety & $\begin{array}{c}\text { Mozart's piano concerto } \\
\text { K.488 }\end{array}$ & $\begin{array}{c}\text { Ad hoc reading } \\
\text { comprehension tests, leaning } \\
\text { anxiety scales from two } \\
\text { previous studies (Venkatesh, } \\
\text { 2000; He, Chang \& Liu, 2010), } \\
\text { and a scale of cognitive load } \\
\text { (Ouyang et al., 2010) }\end{array}$ \\
\hline
\end{tabular}


(B)

Study Main Findings

\section{Statistics Significance}

Hanson-Abromeit [61] $\quad$ ER-related abilities were noted, and acceptability and

Boone \& Cunningham [62]

The majority of the respondents agreed that music and singing help in developing teachers' thinking skills and raise their emotional awareness integration of the intervention into the regular daycare

environment was supported by interview data

Overall, children as young as 4 and 5 years old were able to portray emotional meaning in music through expressive movement. More detailed analysis revealed that this ability was strongest for sad and happy segments and less developed for angry and fearful segments

Whithin an arts-integrated program, children showed greater observed positive emotions, and greater growth in teacher-rated levels of positive and negative emotion regulation

Brown \& Sax [63]

It was found no neural, cognitive, motor, emotional, or social differences among the three groups. In addition, there was no correlation between music perception skills and any of the social or emotional measures

Not applicable

Significant main effects were found for Age, $F(1,43)=4.13$, $p=0.048$, and Emotion,

$F(3,129)=9.07, p<0.001$. Children were more accurate in expressing the emotions of sadness and happiness and less accurate in expressing anger and fear. Additionally, older children were more effective in their communication of emotional meaning.

Children's display of positive emotions in arts classes $(M=4.35, S D=0.60)$ versus early learning classes $(M=3.95, \mathrm{SD}=1.26)$ differed significantly $(t(152)=-3.94, p<0.001)$

Children's display of negative emotions in arts $(M=0.41$, $S D=0.51)$ versus early learning classes $(M=0.45$

$S D=0.86)$ did not differ significantly $(t(152)=0.60, \mathrm{~ns})$

Univariate ANOVA results for each behavioral outcome by group:

Habibi et al. [64]

Mind in the eye: $F(2,42)=1.517, p=0.23$; Index of empathy: $F(2,42)=0.480, p=0.62$

Emotion match: $F(2,42)=0.502, p=0.60$

\section{Main Limitations}

This was a feasibility study, so outcomes should be interpreted with caution due to the small sample size and lack of a comparison group. It should also be noted that this study was conducted with typically developing children at a single daycare site in the southeastern United States, further limiting generalization beyond this study sample. There is n comparison control to demine the efficacy of the MCRF intervention.

In the measurement, teachers referenced music in genera rather than the MCRF intervention specifically

One potential criticism is that the accurate and identifiable portrayal of a music segment's emotional meaning through a dance performance does not stipulate that the performer has cognitively "understood" the emotional message.

Another possible criticism is that the children could be copying what they saw modeled by the experimenter, rather than encoding the emotional meaning

Results showing an advantage of the arts for children's emotions and emotion regulation are specific to Settlement Music Schools Kaleidoscope Preschool Arts Enrichment

Program, Then the results may not apply to programs that use the arts in other ways.

The present research does not uncover how arts exposure might boost emotional functioning, and future research should focus on mechanisms

Gordon's PMAA is a musical aptitude task

that primarily measures perception skills and memory, using an assessment which instead focuses on interpersonal musica experience to correlate with social/emotional skills may be more suitable. It is unclear whether the results are related to cognitive and social and emotional advantages in musicians or the consequence of the participation in an engaging collective activity, or of a combination of various factors.

Results limited to Islam education and not generalizable to other educational contexts 
Table 2. Cont.

\section{Study} Main Findings

Jeremic et al. [67]

Increased social-emotional competencies of students in the experimental group (using the vocal performance teaching method)

\section{Statistics Significance}

Respondents who participated in the instruction carried out by the teacher of music culture showed a statistically significantly higher level of socio-emotional competencies $(p<0.05)$ compared to the control group during the final assessment. At the same time, there were no statistically significant differences in school attendance (Sombor Kikinda) and gender structure of the respondents.

The authors found significant correlations between preference and beauty ratings $(\mathrm{r}=0.334, p=0.003)$, happiness and beauty ratings $(\mathrm{r}=0.516, p<0.001)$, and sadness and ugliness ratings $(\mathrm{r}=0.335, p=0.003)$ for the piece in major (Bonferroni corrected alpha level: $p=0.003$ ). A correlation between happiness and beauty rating scores was also found for the minor piece $(\mathrm{r}=0.456, p<0.001)$ and the free tonal one $(r=0.557, p<0.001)$. Analyzing the groups separately, the authors found significant School-aged children are able to make emotional and
aesthetic judgments about unfamiliar musical piece

Nieminen et al. [65] correlations between happiness and beauty ratings for the major piece $(r=0.475, p=0.003)$ and the free tonal piece $(\mathrm{r}=0.706, p<0.001)$ in $6-7$ year olds. Happiness and beauty ratings were also correlated for the piece in majo $(\mathrm{r}=0.604, p<0.001)$ and the piece in minor mode $(\mathrm{r}=0.516, p<0.001)$ in the group of $8-9$ year-olds

Compared with the untrained children $(M=6.86$

The present findings documented a positive association betweenmusic training and performance on a test of

Schellenberg \& emotional abilities inchildhood. Nevertheless, the link Mankarious [68] appeared to be a consequence ofhigh levels of cognitive functioning among the musically trainedchildren. $S D=0.81$ ) had higher Test of Emotion Comprehension (TEC) total scores, $t(58)=2.86, p=0.006, \eta^{2}=0.12$.
The limitations of the conducted study was the selection of the sample. Specifically, the results of the study would probably have been more valid if the sample had been random.

The music stimuli and musical parameters used in this study were strictly controlled. For this reason this design does not necessarily allow to generalize the results. Moreover, additional refinements regarding the setup and careful

modifications of the music material could be used to explore additional developmental aspects of music cognition and appreciation

The vast majority of music training involved private one-on-one lessons, which require solitary practicing between lessons and have no social component other than playing for the instructor. Future research could examine in greater depth the role played by individual versus group lessons in the social-emotional abilities of musically trained children and

adults, and whether improved emotional abilities are

restricted to emotions conveyed in the auditory domain, or to tests that rely less on cognitive abilities.

The size of the sample. The participating subjects were

An improvement was observed in the feelings experienced the

Not applicable

Integrating popular music, active (personal meaning and
Not applicable

Rauduvaite [70] $\begin{aligned} & \text { emotional imitation) methods of music education can be } \\ & \text { acceptable and efficient for junior school age children }\end{aligned}$

Rauduvaite [70] $\begin{array}{r}\text { emotional imitation) methods of music education can b } \\ \text { acceptable and efficient for junior school age children }\end{array}$

31 students from a public school in Sao Paulo, so the results of this study can not be generalized

The sample of the educational project included only 70 school learners 
Table 2. Cont.

\section{Study} Main Findings

The combination of MI and sandplay was shown to have a positive effect on the improvement of children's self-expression and emotions

Kang [71]

Soulier [72]

Results reveal a negative impact of negative emotional induction on grammatical spelling performances

The musical instrument performance program improved the ability to perceive emotions, and reduced physical and verbal aggression

Kim \& Kim [73]

Children in the music group had larger increases in sympathy and prosocial

Schellenberg et al. [74] but this effect was limited to children who had poor rosocial skills before the lessons began. The results suggest that groupmusic training facilitates the development of prosocial skills

\section{Statistics Significance}

Not applicable

The effect of the emotional induction factor is significant,

(Positive $=33.74 \%$, Negative $=49.58 \%$, Neutral $=39.09 \%$,

$F(2,216)=3.01 ; p=0.05,2 p=0.03)$. Post-hoc analysis reveals a significant difference between the percentages of errors obtained under neutral and negative $(p<0.03)$ and negative emotional induction conditions and positive $(p<0.001)$. No interaction is significant.

There were statistically significant effects of group $F(1,58)=1.474, p=0.016$, time, $\mathrm{F}(1,58)=3.559, p=0.048$, and the interaction of group $\times$ time, $F(1,58)=4.108, p=0.001$, on perceiving emotion (a subcategory of EI), indicating a greater increase in the experimental group compared to the control group during the intervention period. There were statistically significant effects of group, $F(1,58)=1.748, p=0.049$, time, $F(1,58)=3.724, p=0.043$, and the interaction of group $\times$ time $F(1,58)=4.173, p=0.039$, on verbal aggression (a subcategory of aggression), indicating a greater decrease in the

experimental group compared to the control group during the intervention period. Physical aggression also showed statistically significant effects of group, $F(1,58)=1.245$, $p=0.038$, and time, $F(1,58)=0.328, p=0.027$, but not the interaction effect of group $\times$ time, $\mathrm{F}(1,58)=1.129, p=0.176$

For emotion comprehension, there was a stronger two-way interaction between testing time and initial performance, $F(1,80)=38.88, p<0.001$, partial $\eta^{2}=0.327$. Children who scored low at T1 showed marked improvement from T1 $(M=4.41, S D=0.57)$ to $\mathrm{T} 2(M=5.52, S D=1.13)$

$F(1,38)=45.61, p<0.001$, partial $\eta 2=0.546$. High scorers showed no change, $p>0.2$

The results from the ANOVA on sympathy scores revealed three-way interaction between testing time, initial performance and group assignment, $F(1,80)=4.94, p=0.029$, partial $\eta^{2}=0.05$

The analysis of prosocial skills also revealed a three-way interaction between testing time, initial performance and
All participants were recruited from two elementary schools in Seoul, South Korea using a convenience sampling method. Thus, the participants are not representative of all elementary school children

Second, all of the data in this study were from self-reports. Although they guaranteed anonymity and confidentiality to all participants, it is possible that some children might not have answered all the questions honestly. Future studies should include additional informants, such as teachers, peers, and family members.

The possibility that an unknown variable caused some of the improvements in social skills that were apparent to the children in the program cannot be ruled out. It is unknown whether non-musical group activities would have a similar effect on prosocial skills. It is also possible that the

experimenter's expectations play a role, with subtle but unintended cues leading children to respond in the desired way. Unfortunately, the music program was implemented in some schools, but not others, making it impossible for experimenters to be blind to group assignment. 
Table 2. Cont
Study Main Findings

The use of upbeat music and laughing in the experimental condition produced positive mood, thereby facilitating creativity

Teske et al. [75]

AudioGraphics generates higher levels of emotiona satisfaction than dissatisfaction

Venegas et al. [76]

It was found a negative effect of sadness on the scores of correct answers to syllogisms compared to joy. Therefore, creating an atmosphere that favors a positive emotion will

permit children to better use their cognitive competences

Tricard et al. [77]

The results showed that the Orff Approach has a positive effect on children's self-expression, self-efficacy, and

Yun \& Kim [78]

$$
\text { social skills }
$$

The findings suggest that background music can be an effective tool to increase emotional understanding in children with autism, which is crucial to their

$$
\text { social interactions. }
$$

\section{Statistics Significance}

Results indicated a significant difference with a very large effect size between cartoons made during the experimental condition lessons and cartoons made during the control condition lessons ( $p<0.001$ in humor; $p=0.013$ in originality). Apparently, lifting students' moods with upbeat music and laughing affected students' creative use of humor in their cartoons.

There is no significant correlation between positive feelings and appreciation of music and sound (r: 0,201 p: 0,104)

A significant effect of emotional state on performance in deductive reasoning is observed
$[\mathrm{H}(2 ; n=83)=14.72 ; p<0.05]$.

A significant difference is only observed between the "joy" group and the "sadness" group with $[\mathrm{H}(2 ; n=83)=3.69$; $p<0.05]$. The group "joy" solves on average 5.5 syllogisms correctly $(S D=0.82)$ against 4.25 sylllogisms correctly solved $(\mathrm{ET}=1.35)$ for the group "Sadness".

No other difference is significant

The Orf Approach was signifcant to the subject's self-expression $(\mathrm{Z}=-3.92, p<0.001)$. Too was significant to the subject's self-efficacy $(Z=-3.93, p<0.001)$. The efects on the social skills showed a signifcant diference before and after the experiment $(\mathrm{Z}=-3.89, p<0.001)$.

The repeated measures analysis revealed that there was a significant difference in understanding among the four emotions $(F=4.72, d f=3, p=0.01)$. The repeated measures analysis revealed that there was a significant difference among the intervention conditions $(F=9.90, d f=3, p=0.00)$.

\section{Main Limitations}

The current study was limited because it considered the broad variable of elevated mood without separating the effects of upbeat music from simulated laughter. The effects of upbeat music from simulated laughter. The
different effects of upbeat and simulated music laughter could be determined by future experiments that examine these variables separately.

The small number of children in the sample

They do not present the results on the correlations between negative emotions (Rho Spearman) and musical evaluation

Limitations regarding emotional induction and measurement

The experiment in this research was conducted for 6 sessions, once a week, and looked at the short-term changes and improvements in the children.

As the study was targeted at a few low-income children in a limited area it is difficult to generalize

The sample size, participants' diverse ages and verbal abilities, and the time frame for treatment are all factors that may have contributed to the findings of the present study. The sample size was limited to 12 participants so that each counterbalanced treatment order group had only 3 participants.

Students who tend to see the positive side of things have higher self-esteem and self-confidence. Teaching with integrated students' emotional work can improve their performance

Not applicable Prosocial $z=-0.14, p=0.89$ Sympathy $z=-0.41$

$$
\begin{gathered}
p=0.69 \\
\text {. }
\end{gathered}
$$

Prosocial emotions towards the social exclusion of a child with autism can be improved for NT children through

Cook et al. [81] to be a victim decreases. $p=0.69$
Tendency to be a victim $z=-0.183$ $p=0.07$

Tendency to be a bully $z=-0.38$ $p=0.71$
This is a case study with three subjects, so its results are not intended to be generalised
Results from natural experiments are less likely to evidence causation, and

while children were broadly matched in terms of socioeconomic status (SES), ethnic and cognitive profiles, other unknown variables should not be ruled out.

Furthermore, the long-term durability of these findings could not be tested, due to the constraints of this study. 
Table 2. Cont.

Study Main Findings

The gains observed include an improved concentration and attitude to schoolwork as well as the unlocking of creative talent

\section{Statistics Significance}

Not applicable
Lebaka [82]

\section{Main Limitations}

Closer investigation showed that the data on actual composition was difficult to obtain. The origin of these song is not known. Further investigations should be conducted with regard to the collection, retention and transmission of traditional Pedi religious songs so as not to forever lose these important cultural treasures

Results of the ANOVA Oppositional Defiant Problems (OD). $\left(F(3,97)=3.36, p<0.03 ; \eta^{2} p=0.09\right)$

Participation in group drumming led to significant improvements in multiple domains of social-emotional

Ho et al. [83] This sustainable intervention can foster positive youth development and increase student-counselor interaction experience of pleasant emotions contributed to liking sad music.

This piece of Mozart's music had positive effect in reducing Fantasy was directly ass aking ability, was correlated with Aditionally,

The study shows that sound holds the children's interest ven when the image is removed. Furthermore, music has meaning for children in aspects related to emotion

Kawakami \& Katahira [85]
The authors found that liking sad music was significantly correlated with both Empathic Concern (EC) $[r(84)=0.28$ $p<0.05]$ and Fantasy (FS) $[r(84)=0.27, p<0.05]$. In addition, the current data demonstrated that Perspective Taking (PT) was significantly correlated with liking sad music $[r(84)=0.35, p<0.01]$

The learning anxiety scores of both groups when Mozart was played were significantly higher than those seen for the silent task, and thus the students' had lower learning anxiety when listening to this music: Group $1(t=2.319$ $p<0.05)$, Group $2 t=3.148, p<0.01$ )
The effect sizes in the current study $\left(\eta^{2} p=0.09-0.23\right)$ were small due to the sample size and inclusionary approach to recruitment; second, random assignment of classrooms to treatment conditions was not feasible due to school administrative constraints, third, teacher raters were not blinded to the group assignment of the students and, thu may have been prone to reporting bias (this is a major limitation of the pilot study); fourth, the lack of an attention control group and the necessary inclusion of a "gifted" class in the experimental group may have had unintended effects.

The sample size. A research line will continue by adding further individual interpretations, in an attempt to extend our knowledge about the communicative, emotional and musical tendencies in childhood and preadolescence.

First, this study used only sad music as experimental stimuli. It should be carefully assessed whether the relationships

between trait empathy and responses to sad music shown in the this study were un to examine the relationships between the sub-components of trait empathy and music preferences related to emotions other than sadness. Secondly, the developmental aspects of empathic ability might have influenced the results because only elementary school children took part.

This study is based on data obtained using a subjective learning anxiety scale. In order to explore the related issues more objectively, one might consider using an EEG to measure students' learning anxiety. 


\subsection{Sample Description}

Of all the articles analyzed, a total of 1954 subjects were selected $(\bar{x}=75.15, S D=62.78)$. Publication dates were relatively recent with a range from 2001 to 2019 ( $\bar{x}=2014.96$, $\mathrm{SD}=3.96$ ), experiencing linear growth since 2008 (see Figure 2). As for the educational context, $11.54 \%$ of the work was carried out in the field of early childhood education (3-6 years), $73.08 \%$ in primary education (6-12 years), and $15.38 \%$ in extracurricular activities (7-10 years). The topics identified were: the development of emotional intelligence $(50.00 \%)$, divided into perception, assessment, and expression $(42.31 \%)$, and emotional regulation $(7.69 \%)$; the educational and formative benefits $(42.31 \%)$; and the socioemotional benefits $(26.92 \%)$, as shown in Table 3 . However, no articles were found to address the levels of emotional facilitation and understanding identified by Mayer and Salovey's model [87].

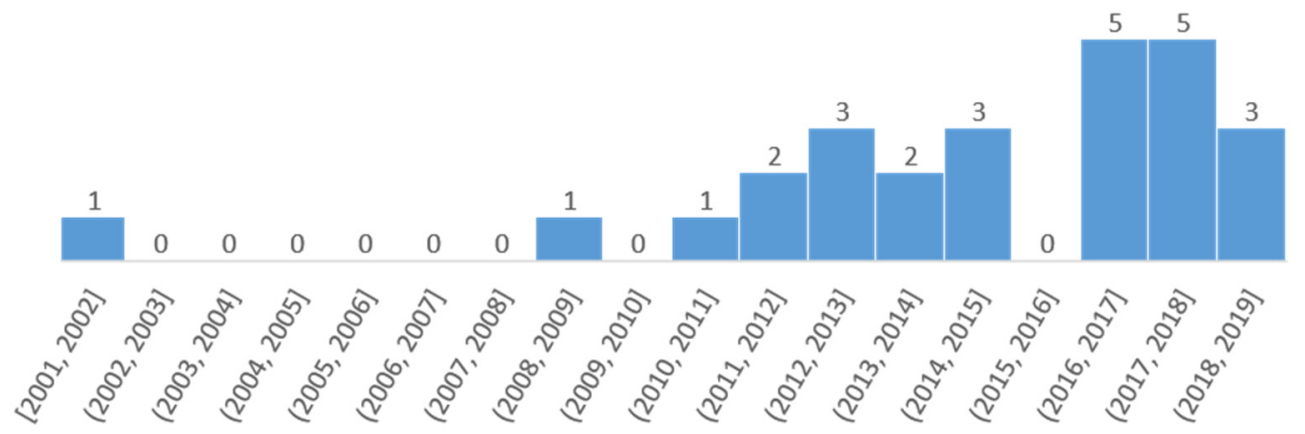

Figure 2. Evolution of publications.

Table 3. Distribution of identified topics.

\begin{tabular}{cccc}
\hline & Topic & Frequency & Examples \\
\hline \multirow{2}{*}{$\begin{array}{c}\text { Emotional } \\
\text { intelligence }\end{array}$} & Perception, assessment and expression & $42.31 \%$ & $\begin{array}{c}\text { Recognition, identification, } \\
\text { expression, discrimination }\end{array}$ \\
\cline { 2 - 4 } Educational and training benefits & $7.69 \%$ & Management, regulation, reaction \\
\hline \multirow{2}{*}{ Socio-emotional benefits } & $42.31 \%$ & $\begin{array}{c}\text { Improvements in spelling, mathematics, } \\
\text { reading comprehension, motivation, } \\
\text { values, creativity }\end{array}$ \\
\hline & $26.92 \%$ & $\begin{array}{c}\text { Reduced Aggressiveness, better } \\
\text { empathy, development of } \\
\text { pro-social skills }\end{array}$ \\
\hline
\end{tabular}

\subsection{Combined Results}

After analyzing the selected studies the results were organised into two lines: (1) dependent variables, a description of the socio-emotional effects/benefits of music; and (2) independent variables, different types of musical experience and their different effects. It should be noted that many authors did not make this distinction, while other co-relational studies did not follow a specific direction in the associations found. However, we attempted to structure these by assigning dependent and independent variables according to the interpretation of the aim of the studies.

\subsection{Organization of the Information on Dependent Variables: What Emotional Effects Are Provided by Music?}

This section was structured on the groups included in Table 3, in which the results are given according to: emotional intelligence, and the educational, training and socioemotional benefits. 


\subsubsection{Emotional Intelligence}

After analyzing the selected articles we found 11 papers divided into two sub-topics: (1) emotional perception, appraisal, and expression, (2) and emotional regulation.

\section{Perception, Assessment and Expression}

Six studies addressed the role of music in relation to emotional perception and assessment. For example, Nieminen [65] observed that students in the first two years of primary school have the ability to identify greater happiness in pieces composed in the major mode than in the minor mode. This relationship was stronger in those with musical training, especially among the younger ones. In a similar vein, Schellenberg and Mankarious [68] measured perceptual differences between a group of students with and without musical training, finding that the former scored higher in identifying emotions in images and/or texts. However, the authors point out that this relationship appears to be mediated by IQ, which may be biased both in terms of participating in formal music education activities and identifying emotions on the basis of a measurement instrument based on visual and linguistic processes.

In relation to specific interventions, Kim and Kim [73] found that the use of a music education program based on group instrumental performance improved students' ability to recognise emotions. Katagiri [79] found in a study conducted with a group of children with autism spectrum disorder that teaching them to recognise emotion is more effective with music than when only verbal instructions are used. In addition, it was found that the use of background music associated with the emotions being worked on obtained better results than nursery rhymes, especially for the emotion of anger, as opposed to happiness, sadness, and fear. Of these above four studies it was deduced that musical entertainment and/or music education can help to recognise emotions in pieces of music, texts, and images, unlike other types of non-musical activities, and that this result can also be applied to specific populations such as children with autism spectrum disorder.

However, another study did not find any effect of music training on Emotional Comprehension in children who began the program with high levels of social skills [74], although it did provide a significant improvement in the children who had poor social skills at the beginning of the study. Along the same lines, Habibi et al. [64] compared the differences between children who participated in after-school activities in music, sports, or who had not enrolled in any specific activity. The study found no significant differences between the three groups in recognising emotional states by viewing pictures of eyes and empathising with the emotions of others, supporting the idea that the differences found in other studies are due to musical experiences.

However, the results in which no difference was found between the musically trained group and the other two groups could have been due to the short training time (5 days per week for two/three weeks). As the authors themselves propose, the differences associated with musical training were found in another longitudinal study with a 14-month training period with 5-7 year old children [88]. However, Habibi et al. [64] considered that their results also give some indirect support for the idea that the kinds of social and emotional skills reported in children who have studied music may be a by-product of music training and designed their study controlling the base line of previous skills in all of the groups, which provided a good base for a complete longitudinal study for the subsequent identification of whether the development of different skills in musical and non-musical adults is specifically due to musical training or to previous skills.

Three papers that deal with emotional expression agree that music can favor emotional expression. For example, Boone and Cunningham [62] found that, between the ages of 4 and 5 years, children are able to physically express some emotions that they perceive through music, such as happiness, sadness, anger, and fear (especially the first two). A study conducted with students from low socio-economic backgrounds concluded that using an Orff-based approach improved their ability to express emotions [78]. Improvement was also observed in a study in which a music therapy program was implemented [61]. 
Emotional Regulation

Two of the articles analyzed dealt with emotional regulation in relation to educational programs including music therapy and concluded that they favored emotional regulation. On the one hand, Brown and Sax [63] compared the emotional state and regulatory capacity of a group of students after attending a traditional education program or a program with a greater emphasis on arts education, including music education. It was found that individuals who participated in the latter showed a greater capacity to regulate emotions, both positive and negative. Moore and Hanson-Abromeit [61] observed that a music therapy program improved a range of behaviors associated with emotional regulation such as aggression, attention and both internal and external attitudes.

\subsubsection{Educational and Training Benefits}

Eleven of the articles analyzed studied the effect of the use of music on the performance of school tasks. For example, Tricard et al. [77] found that video clips and background music to induce joy and sadness caused students who experienced a positive mood to score higher on deductive reasoning activities. Teske et al. [75] also found that students' creativity was enhanced. On the other hand, Venegas et al. [76] found that the use of an interdisciplinary application that used music to support the learning of graphical representation in mathematics generated positive emotional levels in students. Similarly, another study found that greater use of music education increased motivation levels among students [63]. Rauduvaite [70] found that the introduction of urban popular music into the classroom can promote meaningful values in education, partly due to the emotional bond that students have with this type of repertoire.

However, music does not always have only beneficial effects. Su et al. [86] concluded that listening to background music while reading reduces students' anxiety and improves some aspects of their reading comprehension, such as extracting explicit information and making direct inferences. However, other aspects with a higher level of interpretation, such as the integration of ideas or the evaluation of content, language, and textual elements, scored lower. Similarly, Rauduvaite [70] found that the introduction of urban popular music into the classroom can promote meaningful values in education, partly due to the emotional bond that students have with this type of repertoire. Soulier et al. [72] investigated the relationship between a music-induced mood and performance on spelling tasks, concluding that inducing negative emotions through sad music resulted in poorer performance.

Other studies propose indirect methods to promote an emotional state that can improve the performance of school tasks. In the context of a remedial class, Pimenta and Trevisan [69] concluded that the introduction of music, especially choral singing, led to an improvement in the feelings experienced when attending these sessions and a new way of relating to the class, as well as a greater interest and involvement in the class. In a similar way, Ramdane et al. [66] studied the beliefs of a group of Islamic education teachers about the effect of using singing in their classes, and found that the vast majority believed that singing gave them greater emotional awareness and motivation, which could lead to better learning. Similarly, another study found that the use of music with a strong religious-emotional component led students to improve their concentration and creativity [82].

Improving emotional skills can improve the results of music practice. A research study addressed the relationship between emotional skills and instrumental piano practice [80], obtained several results. Firstly, they found that identifying emotions helped students to integrate emotional expression into their piano playing and to play more fluently. Secondly, the type of activities most effective in addressing emotional competence were improvisation and associating the pieces with personal experiences. Thirdly, emotional control allowed for greater organisation of the study, minimising moments of impatience, of playing fast and skipping steps, of not being aware of the music, and of not facing difficulties. Finally, bearing in mind that a public performance is conditioned by concerns about others' judgements, as well as one's own level of self-esteem, it was claimed that the 
variable under study could be enhanced by sharing feelings, collaborating, and helping peers, or achieving a goal through effort.

To sum up, the diverse papers analyzed provide empirical evidence of the effect of music in different areas of education, including the negative effects to be avoided (such as its interference with reading tasks that require a high degree of interpretation) and the positive ones that need reinforcement (e.g., a positive mood to promote learning).

\subsubsection{Socio-Emotional Benefits}

Nine studies found that the use of music enhanced some socio-emotional benefits in diverse areas such as social skills, empathy, and reducing emotional problems. For example, Schellenberg et al. [74] found that students with a musical background scored higher in sympathy and prosocial skills, although only those with lower levels of musical performance. Another study concluded that singing music with a strong emotional component led students to improve in attitude and social skills such as teamwork [82]. Similarly, an intervention based on music education resulted in students developing pro-social emotions in relation to their peers with autism spectrum disorder, especially in cases where the latter were bullied [81]. Kawakami and Katahira [71] studied the relationship between empathic traits and liking sad music, concluding that those individuals with a higher level of concern for the negative experiences of others, greater capacity to adopt the perspective of the other, and greater development of fantastic imagination, experienced more positive emotions when listening to sad music. Porta [81] showed that film music makes sense of the audiovisual narrative and helps to hold children's interest even when they lose the visual part.

Regarding the approach to music education, Jeremić et al. [67] measured differences in the social-emotional competencies of children who were taught singing by a specialist teacher who used an active methodology in which she performed the songs, or by a nonspecialist teacher who played the recordings on audio devices. Significant improvements in social-emotional competencies were found in the experimental group that had used an active method. For example, they were more empathetic towards those who had difficulty with intonation and felt more positive about singing individually. These results suggest that not all of the ways of using music obtain the same effects.

Other studies found a decrease in negative social-emotional attitudes when participating in certain intervention programs that included music. Thus, Ho et al. [83] studied the effect of an experience combining participation in a drumming group with educational counselling on students with low socio-economic backgrounds. The group made significant improvements in behaviors such as anxiety, depression, post-traumatic stress disorder, inattention, and some defiant attitudes. In the same direction, Kang [71] investigated the effect of a therapy based on the use of music (singing, listening, and performing) and sand play in children who had witnessed domestic violence. The author observed that individuals showed improvements related to emotional behavioral problems such as depression, anxiety, aggression, oppositional behavior, and post-traumatic stress. Finally, it was observed that the use of a music education program based on group instrumental performance reduced physical and verbal aggression [73].

Although there have not been a great number of studies performed that show the socio-emotional benefits, they all provide diverse methods for using music to improve these skills.

\subsection{Organizing Information by the Independent Variables: What Types of Musical Experience Have What Types of Socio-Emotional Effects?}

Ten studies used listening to music as the independent variable to compare its effects in different emotional areas and in general found them to be beneficial. Nieminen et al. [65] showed that children better identified their emotions according to major or minor chords. Su et al. [86] concluded that background music improved students' moods, and thus indirectly other skills such as reading comprtehension. Porta [84] found sound held children's interest even in the absence of images and that music had a significance for 
children in aspects related to emotions. Tricard et al. [77] found that videoclips and background music promote positive emotions in children and a significant improvement in deductive reasoning. Teske et al. [75] found that happy music promotes a positive mood and creativity. Katagiri [79] found that background music increases emotional comprehension in autistic children. Rauduvaite [70] found that popular music helped children's education due to their emotional tie with this repertory. Finally, Boone \& Cunningham [62] found that children could represent the emotional significance of music by expressive movements, especially the sad and happy moments. One of the controversial aspects was the effect of sad music on children: while Kawakami \& Katahira [85] found that empathic children enjoy sad music, Soulier [72] found that inducing negative emotions through sad music reduced their concentration on spelling tasks.

Fourteen studies used musical training as the independent variable and obtained evidence that it improved diverse socio-emotional competencies, including: identifying emotions in images and/or texts [68]; a greater capacity to regulate emotions [63]; concentration and creativity [82]; students' ability to recognise emotions [73]; improved learning and mathematics [76]; a positive effect on children's self-expression, self-efficacy, and social skills [78]; improved the feelings experienced when attending class [69]; greater emotional awareness and motivation from singing [66]; increased empathy and positive feelings for learning [67]; influenced the effects of emotional understanding [64]; influenced emotional awareness, regulation and autonomy [80]; increased pro-social behavior in neurotypical children in relation to the social exclusion of autistic children [74]; promoted the development of pro-social skills [81]; improved behaviors such as anxiety, depression, post-traumatic stress disorder, inattention and some defiant attitudes [83]; and increased children's motivation and thus their learning capacity [66].

Finally, two studies used a musical therapy program as the independent variable and found improved emotional behavioral problems, including depression [71] and children's emotional comprehension and emotional regulation [61].

\section{Discussion}

This systematic review seeks to understand the role that music plays in the emotional education of children in infant and primary education. The scientific literature indicates, on the one hand, that in all educational processes there is an emotional component that conditions the teaching-learning process [1]. On the other hand, today's society demands individuals who are increasingly able to adapt to change [21], and with the skills to work collaboratively [20]. This has led to the implementation of various educational programs that seek to introduce the development of emotional competence in the classroom $[4,5,22]$. At the same time, some studies belonging to the fields of Psychology [8-11], Neuroscience [13-16], and Behavioral Sciences [17,18] have investigated the importance of emotional education in the education system. In addition, the central role of music has been demonstrated in aspects such as emotional expression, emotional induction, and emotional regulation [29-38,44-47].

Starting from this conceptual framework, this review aims to systematise the knowledge accumulated through the research works of the last two decades with samples made up of individuals from 3 to 12 years of age. The 26 articles analyzed indicate that publications on this topic have experienced a linear growth since 2008, that most of the research is carried out in the context of primary education, and that the topics most frequently dealt with are the development of emotional intelligence [87], educational and training benefits, and socio-emotional benefits.

With regard to the first aims, two studies have observed that students with musical training have a greater facility for recognising emotions $[65,68]$. The attribution of this effect to musical experiences is reinforced by a study that found no differences prior to such training $[64,74]$. Other studies have shown how certain educational interventions using music led to improvements in the emotional recognition of students [73,79]. However, caution should be exercised with these results, as Schellenberg et al. [74] found no 
differences between children with and without musical training, whereas Schellenberg and Mankarious [68] point out that the relationship could be mediated by IQ, which would act as a bias. In this regard, it would be interesting for future research to experiment with measurement instruments that do not depend on the cognitive abilities of the participants.

In relation to the two studies $[64,74]$ that found no differences between the groups with and without musical training in emotional recognition skills, we consider that the results, in spite of being the opposite of those expected, do not invalidate the general statement that music favors emotional perception and assessment. This is because firstly it provides evidence that music is an especially efficient instrument for children who had poor social skills at the beginning of the study, and secondly it emphasises the need to control the participants' basic levels and carry out longitudinal studies long enough to capture the improvements produced while establishing relationships that specifically assolciate these benefits with musical training.

Similarly, it has been found that the use of proposals that include music improves children's capacity for emotional expression $[61,78]$, who are able to express perceived emotions through music from the age of $4-5$ years old [62]. Emotional regulation also benefits when methodologies in which music plays a central role are used [61,63]. Therefore, the results obtained suggest that the use of music, whether in the form of specific ongoing training or one-off interventions, improves some aspects of emotional intelligence [87], especially emotional perception, expression, and regulation.

This is consistent with some studies that argue that music has a remarkable capacity to express, transmit, and evoke diverse emotions and affections in human beings. Thus, for example, Flores-Gutierrez \& Diaz [29] claim that there are musical sequences that stimulate a specific group of emotions and others that evoke a more general response to a type of emotion that has a certain polarity, such as being pleasant and vigorous. Thus, in their study they find music that globally stimulates one of the four major axes defined in their circular affective model, such as pleasant (Mozart), unpleasant (Mussorgski), exciting (Metallica), or relaxing (Japanese music) emotions. For their part, Thompson \& Quinto [30] claim that the power of music to elicit emotion lies in its ability to engage participants in tightly controlled synchronisation at multiple levels of abstraction. Music optimally recruits synchronisation processes that are ubiquitous in human behavior and that greatly influence our emotional lives.

This ability to express, transmit, and evoke diverse emotions and affects is, moreover, independent of the culture to which one belongs. Balkwill \& Thompson [31] demonstrated that naïve listeners from different cultures obtained as high a level of agreement in their emotional responses to music as expert listeners, who were deeply familiar with the culture-specific cues embedded in the music samples.

On the other hand, music helps emotional regulation. In this regard, Randall et al. [45] conducted research in which they found that using music to regulate a recently experienced emotion achieved the greatest hedonic success. For these authors, personal music listening is used as an independent regulatory resource, allowing listeners to achieve specific emotional goals. Saarikallio \& Erkkilä, [47] conducted a study to recognise music's role in mood regulation in adolescents. The study showed that listening or performing music has an impressive capacity to promote emotional self-regulation. In this regard, music offered adolescents resources to enhance and restore well-being, making their emotional lives more varied and colorful. In addition, Saarikallio [46] asserts that the general nature of music-related emotional self-regulation remains relatively similar throughout adulthood.

It therefore seems reasonable to think that the educational use of music may contribute to students' development of some dimensions of emotional intelligence. However, none of the work addresses the levels of emotional facilitation and understanding reported by Mayer and Salovey [87] in their model. This could be due to the fact that these are higher level skills with a higher level of complexity and abstraction that are beyond the developmental possibilities of infant and primary school students. Future work should 
explore the possibilities of developing these levels of emotional competence in schoolage children.

In relation to the educational and formative benefits, the results indicate that music can play a role in triggering positive emotional states [75-77] and higher levels of motivation, concentration, and interest $[63,66,69,70,82]$, which promotes learning in the classroom. It can also reduce the occurrence of negative emotional states such as anxiety and depression [86]. These benefits have been observed in relation to different school contents, such as improving deductive reasoning [77], creativity [75], graphic representation [76], reading [86], education in values [70], orthography [72], or instrumental practice [80].

These results are consistent with other research that has found music activities such as instrumental performance or improvisation stimulate cognitive processes [48-51], and that they are able to support learning in other disciplines. Johnson \& Memmott [27], in a study of 4739 children, demonstrated the relationship between the quality of music instruction and academic performance on standardised tests in English and mathematics. For these authors, music is a very useful tool to support academic performance. On the other hand, Rickard et al. [28] conducted a study with 151 schoolchildren on the impact of school music programs on verbal and visual memory processes over a two-year period. The results revealed that schools with high-quality music programs performed better on standardized tests than students in schools with lower-quality music offerings.

Finally, in terms of socio-emotional benefits, the articles reviewed agree that both music training and music education can be beneficial for students' social and emotional development [74], such as the fact that the use of music in educational and therapeutic processes $[81,82]$ can have a positive impact on the development of social skills in which some kind of emotion comes into play, such as empathy, teamwork, the development of a pro-social attitude or self-esteem. Similarly, they can contribute to the reduction of negative socio-emotional attitudes such as depression, anxiety, aggression, inattention, defiant and oppositional behavior, or post-traumatic stress $[71,73,83]$. These benefits coincide with some of the challenges posed by today's society, which requires social subjects with high intrapersonal and interpersonal skills that allow them to work in teams and adapt to change $[1,20,21]$.

Specific educational programs that encourage the development of pro-social skills include participation in a drumming group [83], group musical performance [73], or training in singing through a specialist teacher who used her voice in the classroom [67]. These results seem to indicate that the use of music has the capacity to bring social-emotional benefits insofar as it is experiential and fosters personal relationships. This is consistent with some authors who point out that music often involves a series of social interactions that favor socio-emotional learning [55-57]. Moreover, it coincides with the ethnomusicological perspective that conceives of music as a socio-cultural phenomenon that requires cooperation and coordination [54]. This perspective would also contribute to broadening the theoretical basis that justifies the use of active methodologies in the classroom as opposed to more traditional models focused on theory, technique, and individual learning [89-92]. In further research, it would be useful to study not only the greater or lesser use of music, but also the methodology implemented. In this regard, the comparison between the effects produced by traditional, active, and critical pedagogical models would be a valuable contribution to the field of emotional education, as they could be used to guide teachers in their educational practices and to design both initial and ongoing professional training programs.

Regarding the different musical experiences, it was found that both exposure to music, musical entertainment, and musical therapy programs provide improvements in the emotional sphere.

\section{Conclusions}

This systematic review found that using music in the education of 3-12 year olds can have a positive effect on their emotional development. We first found that it can 
contribute to the development of emotional intelligence, especially with regard to emotional perception, expression, and regulation. The students that took part in activities using music were more capable of recognising and expressing their emotions and regulating their emotional states, such as aggression or anger. Secondly we found that music is capable of providing educational, formative, and socio-emotional benefits. In this regard its emotional impact can improve aspects such as deductive reasoning, creativity, graphic representation, reading, spelling, education in values, or practical instrumental skills. It can also boost attitudes such as sympathy, empathy, and other prosocial skills, and reduce anxiety, depression, and defiant attitudes. It is therefore recommended that music be incorporated into the different curricular levels, educational contexts, and areas of knowledge. Likewise, the establishment of educational policies aimed at guaranteeing universal access to musical training is suggested, as well as an increase in the presence and recognition of this discipline in formal educational contexts.

Most of the limitations encountered in this study were due to the considerable heterogeneity in the different studies selected, which made it difficult to integrate them into a single framework. All the studies used different independent variables, such as musical listening, entertainment, or music therapy, and different dependent variables such as different emotional effects or in the development of socio-emotional skills. We therefore had to integrate and synthesize the information into a scheme to make sense of the results. However, our double approach to structuring the results (first by the socio-emotional effects and then by the musical variables) allowed us to better structure them, although it was a difficult and complex task.

We should first of all point out that the studies came from different disciplines such as musical education, music psychology, music teaching, music therapy, etc., and thus different researchers used their own theories, methods, nomenclatures, and instruments, which made it difficult to combine the results in a common language. The second difficulty was the lack of a classification with a wide consensus of positive emotions or emotional skills. Psychology is known to classically study psychopathology and has classified the universally accepted diverse psychological disorders (e.g., Diagnostic and Statistical Manual of Mental Disorders (DSM-V) [93] and the International Classification of Diseases (CIE10) [94]). These serve as a guide to researchers who can compare their results using these classifications. However, until the emergence of Positive Psychology in the first decade of the 21st century this discipline had not focused on the positive aspects of human existence, so that there were still no official classifications of the positive emotional sphere that were generally accepted by all researchers

The present work aimed to find positive emotional aspects, and although we used studies from the year 2000 these were not based on a common taxonomy regarding the measurement and classification of these effects. However, we had serious difficulty in integrating the results into a common scheme, although we got some support from Mayer \& Salovey's Theory of Emotional Intelligence [87], which includes different emotional facets and skills and is widely recognized in scientific fields. Thirdly, we should point out that there are overlaps and covariances among the dependent variables (e.g., if we improve emotional recognition the socio-emotional skills will probably also improve) and in the independent variables (e.g., musical entertainment programs include listening and music therapy). This makes it difficult to ascertain the relations between the variables and alerts us to the need for a more experimental approach in this field that uses common categories to construct more solid knowledge.

Fourthly, we were not able to extract solid syntheses and conclusions from homogenous groups in diverse variables of interest (e.g., specific ages, music styles, different levels of empirical evidence) due to the lack of appropriate studies. We opted for a generic search in order to deal with the wide range of papers. A narrower search would have provided greater precision with more homogeneous results but less information, counting on a small number of papers for the systematic review. We therefore consider that our approach 
achieved a balance between information and precision, since it allowed us to draw a map of the present situation and integrate this information into a joint scheme.

The wide fragmentation of the papers is an indication of the relatively recent emergence of this field of study, which associates music education with its emotional effects. However, we consider that studies such as this will allow us to detect the obstacles and deficiencies in order to go on constructing the basis of a common language to improve the comparison of the results and the advances in clarifying the empirical evidence in relation to the effects of musical education in the socio-emotional area.

Author Contributions: Conceptualization, J.S.B.-M., G.B.-V., and P.M.-L.; methodology, J.S.B.-M., P.M.-L., and C.M.-T.; investigation, J.S.B.-M., G.B.-V. and P.M.-L.; data curation, J.S.B.-M., C.M.-T. and P.M.-L.; writing-original draft preparation, J.S.B.-M., G.B.-V. and P.M.-L.; writing-review and editing, J.S.B.-M.; P.M.-L., and G.B.-V.; supervision, G.B.-V., and C.M.-T. All authors have read and agreed to the published version of the manuscript.

Funding: This work was funded by the Faculty of Psychology of the Catholic University of Valencia San Vicente Mártir under Grant (number 2021-198-001).

Institutional Review Board Statement: Not applicable.

Informed Consent Statement: Not applicable.

Conflicts of Interest: The authors declare no conflict of interest.

\section{References}

1. Cefai, C.; Cooper, P. Innovative learning for all. In Promoting Emotional Education: Engaging Children and Young People with Social, Emotional and Behavioural Difficulties; Jessica Kingsley Publishers: London, UK, 2009.

2. Campayo-Muñoz, E.Á.; Cabedo-Mas, A. The role of emotional skills in music education. Br. J. Music Educ. 2017, 34, 243-258. [CrossRef]

3. Salovey, P.; Mayer, J.D. An Intelligent Look at Emotional Intelligence. Imagin. Cogn. Pers. 1990, 9, 185-211. [CrossRef]

4. Payton, J.W.; Wardlaw, D.M.; Graczyk, P.A.; Bloodworth, M.R.; Tompsett, C.J.; Weissberg, R.P. Social and emotional learning: A framework for promoting mental health and reducing risk behavior in children and youth. J. Sch. Health 2000, 70, 179-185. [CrossRef] [PubMed]

5. Bisquerra, R. Educación emocional y competencias básicas para la vida. Rev. Investig. Educ. 2003, 21, 7-43.

6. Delors, J. La Educación encierra un tesoro. In Informe a la UNESCO de la Comisión Internacional Sobre la Educación para el Siglo XXI; Santillana-Unesco: Madrid, Spain, 1996.

7. Acosta, A. Educación Emocional y Convivencia en el Aula; Ministerio de Educación: Madrid, Spain, 2008.

8. Schutz, P.A.; Lanehart, S.L. Introduction: Emotions in education. Educ. Psychol. 2002, 37, 67-68. [CrossRef]

9. Schutz, P.A.; Pekrun, R. Emotions in Education; California Academic: San Diego, CA, USA, 2007.

10. Macklem, G. Evidence-Based School Mental Health Services: Affect Education, Emotion Regulation Training, and Cognitive Behavioral Therapy; Springer Science \& Business Media: New York, NY, USA, 2014.

11. Pekrun, R.; Linnenbrick-García, L. International Handbook of Emotions in Education; Routledge: New York, NY, USA, 2014.

12. Turner, J.E.; Husman, J.; Schauert, D.L. The importance of students' goals in their emotional experience of academic failure: Investigating the precursors and consequences of shame. Educ. Psychol. 2002, 37, 79-89. [CrossRef]

13. Martin, R.E.; Ochsner, K.N. The neuroscience of emotion regulation development: Implications for education. Curr. Opin. Behav. Sci. 2016, 10, 142-148. [CrossRef]

14. Immordino-Yang, M.H. Implications of affective and social neuroscience for educational theory. Educ. Philos. Theory 2011, 43, 98-103. [CrossRef]

15. Immordino-Yang, M.H.; Damasio, A. We Feel, Therefore We Learn: The Relevance of Affective and Social Neuroscience to Education. Learn. Landsc. 2007, 1, 3-10. [CrossRef]

16. Immordino-Yang, M.H. Emotions, Learning, and the Brain: Exploring the Educational Implications of Affective Neuroscience; Norton and Company: New York, NY, USA, 2015.

17. Simpson, R.L.; Peterson, R.L.; Smith, C.R. Critical Educational Program Components for Students with Emotional and Behavioral Disorders: Science, Policy, and Practice. Rem. Spec. Educ. 2011, 32, 230-242. [CrossRef]

18. Gable, R.A.; Tonelson, S.W.; Sheth, M.; Wilson, C.; Park, K.L. Importance, usage, and preparedness to implement evidence-based practices for students with emotional disabilities: A comparison of knowledge and skills of special education and general education teachers. Educ. Treat. Child. 2012, 35, 499-519. [CrossRef]

19. Cefai, C.; Cavioni, V. Social and Emotional Education in Primary School: Integrating Theory and Research into Practice; Springer Science \& Business Media: New York, NY, USA, 2013. 
20. Hake, B.J. Lifelong learning in the late modernity: The challenges to society, organizations and individuals. Adult Educ. Q. 1999, 49, 79-90. [CrossRef]

21. Bornstein, D. How to change the world. In Social Entrepreneurs and the Power of New Ideas; Penguin Books: London, UK, 2003.

22. Saarni, C. The Development of Emotional Competence; Guilford Press: New York, NY, USA; London, UK, 1999.

23. Carrillo, C.; Viladot, L.; Pérez-Moreno, J. Impact of music education: A review of the scientific literatura. Rev. Electrónica Complut. Investig. Educ. Music. 2017, 14, 61-74. [CrossRef]

24. Hernández-Bravo, J.R.; Cardona-Moltó, M.C.; Hernández-Bravo, J.A. The effects of an individualised ICT-based music education programme on primary school students' musical competence and grades. Music Educ. Res. 2016, 18, 176-194. [CrossRef]

25. Hogenes, M.; Van Oers, B.; Diekstra, R.F.W.; Sklad, M. The effects of music composition as a classroom activity on engagement in music education and academic and music achievement: A quasi-experimental study. Int. J. Music Educ. 2016, 34, 32-48. [CrossRef]

26. Jorgensen, E.R. Transforming Music Education; Indiana University Press: Bloomington, IN, USA, 2003.

27. Johnson, C.M.; Memmott, J.E. Examination of relationships between participation in school music programs of differing quality and standardized test results. J. Res. Music Educ. 2006, 54, 293-307. [CrossRef]

28. Rickard, N.S.; Vasquez, J.T.; Murphy, F.; Gill, A.; Toukhsati, S.R. Benefits of a classroom based instrumental music program on verbal memory of primary school children: A longitudinal study. Aust. J. Music Educ. 2010, 1, 36-47.

29. Flores-Gutiérrez, E.; Díaz, J.L. La respuesta emocional a la música: Atribución de términos de la emoción a segmentos musicales. Salud Ment. 2009, 32, 21-34.

30. Thompson, W.F.; Quinto, L. Music and Emotion: Psychological Considerations. In The Aesthetic Mind: Philosophy and Psychology; Schellekens, E., Goldie, P., Eds.; Oxford University Press: Oxford, UK, 2011.

31. Balkwill, L.L.; Thompson, W.F. A cross-cultural investigation of the perception of emotion in music: Psychophysical and cultural cues. Music Percept. 1999, 17, 43-64. [CrossRef]

32. Eerola, T.; Friberg, A.; Bresin, R. Emotional expression in music: Contribution, linearity, and additivity of primary musical cues. Front. Psychol. 2013, 4, 1-12. [CrossRef] [PubMed]

33. Eerola, T.; Vuoskoski, J.K. A review of music and emotion studies: Approaches, emotion models, and stimuli. Music Percept. 2013, 30, 307-340. [CrossRef]

34. Juslin, P.N.; Västfjäll, D. Emotional responses to music: The need to consider underlying mechanisms. Behav. Brain Sci. 2008, 31. [CrossRef]

35. Koelsch, S. Towards a neural basis of music-evoked emotions. Trends Cogn. Sci. 2010, 14, 131-137. [CrossRef]

36. Sloboda, J.A.; Juslin, P.N. At the interface between the inner and outer world: Psychological perspectives. In Handbook of Music and Emotion; Oxford University Press: Oxford, UK, 2010; pp. 73-97.

37. Juslin, P.N.; Sloboda, J.A. Music and Emotion: Theory and Reseach; Oxford University Press: New York, NY, USA, 2001.

38. Gabrielsson, A. Emotion perceived and emotion felt: Same and different. Music. Sci. 2002, 6, 123-148. [CrossRef]

39. Hodges, D. Psychophysiological measures. In Handbook of Music and Emotion: Theory, Research, Applications; Oxford University Press: Oxford, UK, 2010; pp. 279-311.

40. Juslin, P.N. Music and emotion: Seven questions, seven answers. En Music and the Mind: Essays in Honour of John Sloboda; Deliège, I., Davidson, J.W., Eds.; Oxford University Press: Oxford, UK, 2011; pp. 113-135.

41. Koelsch, S. Brain and Music; Wiley-Blackwell: Oxford, UK, 2012.

42. Reimer, B. New Brain Research on Emotion and Feeling: Dramatic Implications for Music Education. Arts Educ. Policy Rev. 2004, $106,21-27$.

43. Blood, A.J.; Zatorre, R.J. Intensely pleasurable responses to music correlate with activity in brain regions implicated in reward and emotion. Proc. Natl. Acad. Sci. USA 2001, 98, 11818-11823. [CrossRef] [PubMed]

44. Koelsch, S. Music-evoked emotions: Principles, brain correlates, and implications for therapy. Ann. N. Y. Acad. Sci. 2015, 1337, 193-201. [CrossRef]

45. Randall, W.M.; Rickard, N.S.; Vella-Brodrick, D.A. Emotional outcomes of regulation strategies used during personal music listening: A mobile experience sampling study. Music. Sci. 2014, 18, 275-291. [CrossRef]

46. Saarikallio, S. Music as emotional self-regulation throughout adulthood. Psychol. Music 2011, 39, 307-327. [CrossRef]

47. Saarikallio, S.; Erkkilä, J. The role of music in adolescents' mood regulation. Psychol. Music 2007, 35, 88-109. [CrossRef]

48. Biasutti, M. Pedagogical applications of cognitive research on musical improvisation. Front. Psychol. 2015, 6, 1-12. [CrossRef]

49. Hanna-Pladdy, B.; MacKay, A. The Relation Between Instrumental Musical Activity and Cognitive Aging. Neuropsychology 2011, 25, 378-386. [CrossRef]

50. Peretz, I.; Zatorre, R.J. The Cognitive Neuroscience of Music; Oxford University Press: Oxford, UK, 2003.

51. Serafine, M.L. Music as Cognition: The Development of Thought in Sound; Columbia University Press: New York, NY, USA, 1988.

52. Schaefer, H.E. Music-evoked emotions-Current studies. Front. Neurosci. 2017, 11, 1-27. [CrossRef]

53. Blasco, J.S.; Calatrava, C. Influencia de la Música en las Emociones Percibidas en el Alumnado de Educación Secundaria y Bachillerato; Universidad de Almería: Almería, Spain, 2020. [CrossRef]

54. Merriam, A.P. The Anthropology of Music; Northwestern University Press: Evanston, IL, USA, 1964.

55. Kaschub, M. Defining emotional intelligence in music education. Arts Educ. Policy Rev. 2002, 103, 9-15. [CrossRef] 
56. Pellitteri, J.S. The use of music in facilitating emotional learning. In Emotionally Intelligent School Counseling; Pellitteri, J.S., Stern, R., Shelton, C., Eds.; Erlbaum: Mahwah, NJ, USA, 2006.

57. Edgar, S.N. Introducing Social Emotional Learning to Music Education Professional Development. Updat. Appl. Res. Music Educ. 2013, 31, 28-36. [CrossRef]

58. Hallam, S. The power of music: Its impact on the intellectual, social and personal development of children and young people. Int. J. Music Educ. 2010, 28, 269-289. [CrossRef]

59. Hallam, S. The Power of Music-A Research Synthesis on the Impact of Actively Making Music on the Intellectual, Social and Personal Development of Children and Young People. Voices World Forum Music Ther. 2015, 16. [CrossRef]

60. Moher, D.; Liberati, A.; Tetzlaff, J.; Altman, D.G.; Altman, D.; Antes, G.; Atkins, D.; Barbour, V.; Barrowman, N.; Berlin, J.A.; et al. Preferred reporting items for systematic reviews and meta-analyses: The PRISMA statement. PLoS Med. 2009, 6. [CrossRef]

61. Moore, K.S.; Hanson-Abromeit, D. Feasibility of the Musical Contour Regulation Facilitation (MCRF) Intervention for Preschooler Emotion Regulation Development: A Mixed Methods Study. J. Music Ther. 2018, 55, 408-438. [CrossRef]

62. Boone, R.T.; Cunningham, J.G. Children's Expression of Emotional Meaning in Music Through Expressive Body Movement. J. Nonverbal Behav. 2001, 25, 21-41. [CrossRef]

63. Brown, E.D.; Sax, K.L. Arts enrichment and preschool emotions for low-income children at risk. Early Child. Res. Q. 2013, 28, 337-346. [CrossRef]

64. Habibi, A.; Ilari, B.; Crimi, K.; Metke, M.; Kaplan, J.T.; Joshi, A.A.; Leahy, R.M.; Shattuck, D.W.; Choi, S.Y.; Haldar, J.P.; et al. An equal start: Absence of group differences in cognitive, social, and neural measures prior to music or sports training in children. Front. Hum. Neurosci. 2014, 8, 1-11. [CrossRef]

65. Nieminen, S.; Istók, E.; Brattico, E.; Tervaniemi, M. The development of the aesthetic experience of music: Preference, emotions, and beauty. Music. Sci. 2012, 16, 372-391. [CrossRef]

66. Ramdane, T.; Souad, M.; Marusin, R.; Sidek, S.S. The usefullness of music as a tool of teaching islamic education: Teachers' perspective. Al-Shajarah J. Isl. 2018, 267-286.

67. Jeremić, B.; Šimonji-Černak, R.; Markov, Z.; Pantić, J. The Effects of Applying the Vocal Performance Teaching Method on the Social-Emotional Competencies (SEC) of Children in Early Education. Croat. J. Educ. 2015, 17, 151-185. [CrossRef]

68. Schellenberg, E.G.; Mankarious, M. Music training and emotion comprehension in childhood. Emotion 2012, 12, 887-891. [CrossRef]

69. Pimenta, M.A.; Trevisan, V.L. Música e psicologia na escola: Mobilizando afetos na classe de recuperação. Psicol. Esc. Educ. 2018, 22, 17-25. [CrossRef]

70. Rauduvaite, A. The Educational Aspects of Integrating Popular Music into Lessons. Rural Environ. Educ. Personal. 2018, 11, 94-100. [CrossRef]

71. Kang, H.-J. Supportive music and imagery with sandplay for child witnesses of domestic violence: A pilot study report. Arts Psychother. 2017, 53, 72-79. [CrossRef]

72. Soulier, L.; Largy, P.; Simoës-Perlant, A. Effect of emotional induction by music on the production of nominal and verbal agreements: A study on primary-school children. Annee Psychol. 2017, 117, 405-431. [CrossRef]

73. Kim, H.S.; Kim, H.S. Effect of a musical instrument performance program on emotional intelligence, anxiety, and aggression in Korean elementary school children. Psychol. Music 2018, 46, 440-453. [CrossRef]

74. Schellenberg, E.G.; Corrigall, K.A.; Dys, S.P.; Malti, T. Group music training and children's prosocial skills. PLoS ONE 2015, 10, 1-14. [CrossRef]

75. Teske, J.; Clausen, C.K.; Gray, P.; Smith, L.L.; Al Subia, S.; Rod Szabo, M.; Kuhn, M.; Gordon, M.; Rule, A.C. Creativity of third graders' leadership cartoons: Comparison of mood-enhanced to neutral conditions. Think. Ski. Creat. 2017, 23, 217-226. [CrossRef]

76. Venegas, M.A.; Tejada, J.; Cadiz, R.F.; De la Cuadra, P.; Thayer, T.; Lecaros, A.; Petrovich, M. Audiográficos: Implementación y evaluación de un programa informático para el aprendizaje de la interpretación y representación matemática de coordenadas a través de la música y el sonido. Rev. Electron. LEEME 2013, 32, 135-155. [CrossRef]

77. Tricard, E.; Maintenant, C.; Pennequin, V. Effect of the emotional valence induced on deductive reasoning in children of 9-10 years. Neuropsychiatr. Enfance. Adolesc. 2018, 66, 203-209. [CrossRef]

78. Yun, Y.-B.; Kim, J. The Effects of the Orff Approach on Self-Expresion, Self-Efficacy, and Social Skills of Children in Low-Income Families in South Korea. Child. Welf. 2013, 92, 123-159.

79. Katagiri, J. The effect of background music and song texts on the emotional understanding of children with autism. J. Music Ther. 2009, 46, 15-31. [CrossRef]

80. Campayo-Muñoz, E.; Cabedo-Mas, A.; Hargreaves, D. Intrapersonal skills and music performance in elementary piano students in Spanish conservatories: Three case studies. Int. J. Music Educ. 2020, 38, 93-112. [CrossRef]

81. Cook, A.; Ogden, J.; Winstone, N. The impact of a school-based musical contact intervention on prosocial attitudes, emotions and behaviours: A pilot trial with autistic and neurotypical children. Autism 2019, 23, 933-942. [CrossRef]

82. Lebaka, M.E.K. Analysis of traditional Pedi religious songs for curricular application in primary school. Skriflig Luce Verbi 2014, 48, 1-8. [CrossRef]

83. Ho, P.; Tsao, J.C.I.; Bloch, L.; Zeltzer, L.K. The impact of group drumming on social-emotional behavior in low-income children. Evid. Based Complement. Altern. Med. 2011, 1, 1-14. [CrossRef] 
84. Porta, A. The music that children listen to in movies, series and TV documentaries. An empirical study on its meaning. Int. Rev. Aesthet. Sociol. Music 2018, 49, 311-332.

85. Kawakami, A.; Katahira, K. Influence of trait empathy on the emotion evoked by sad music and on the preference for it. Front. Psychol. 2015, 6, 1-9. [CrossRef]

86. Su, Y.N.; Kao, C.C.; Hsu, C.C.; Pan, L.C.; Cheng, S.C.; Huang, Y.M. How does Mozart's music affect children's reading? The evidence from learning anxiety and reading rates with e-books. Educ. Technol. Soc. 2017, 20, 101-112.

87. Mayer, J.D.; Salovey, P. What is emotional intelligence? In Emotional Development and Emotional Intelligence: Implications for Educators; Salovey, P., Sluyter, D., Eds.; Basic Books: New York, NY, USA, 1999; pp. 3-31.

88. Schlaug, G.; Norton, A.; Overy, K.; Winner, E. Effects of music training on the child's brain and cognitive development. Ann. N. Y. Acad. Sci. 2005, 1060, 219-239. [CrossRef]

89. Green, C.J. Toward young children as active researchers: A critical review of the methodologies and methods in early childhood environmental education. J. Environ. Educ. 2015, 46, 207-229. [CrossRef]

90. Konopka, C.L.; Adaime, M.B.; Mosele, P.H. Active Teaching and Learning Methodologies: Some Considerations. Creat. Educ. 2015, 6, 1536-1545. [CrossRef]

91. Vergara, D.; Paredes-Velasco, M.; Chivite, C.; Fernández-Arias, P. The challenge of increasing the effectiveness of learning by using active methodologies. Sustainability 2020, 12, 8702. [CrossRef]

92. De Stasio, S.; Benevene, P.; Pepe, A.; Buonomo, I.; Ragni, B.; Berenguer, C. The interplay of compassion, subjective happiness and proactive strategies on kindergarten teachers' work engagement and perceived working environment fit. Int. J. Environ. Res. Public Health 2020, 17, 4869. [CrossRef]

93. Psychiatric Association American. Diagnostic and Statistical Manual of Mental Disorders, 5th ed.; American Psychiatric Association: Washington, DC, USA, 2013.

94. Ministerio de Sanidad, Servicios Sociales e Igualdad. Clasificación Internacional De Enfermedades 10a Revisión, 2nd ed.; Ministerio de Sanidad, Servicios Sociales e Igualdad: Madrid, Spain, 2018. 